Digitalizacja archiwalnych numerów czasopisma naukowego Analecta Cracoviensia 1-24 (1969-1992) i ich publikacja w otwartym dostępie - zadanie finansowane w ramach umowy 672/P-DUN/2017 ze środków Ministra Nauki i Szkolnictwa Wyższego przeznaczonych na działalność upowszechniającą naukę

\author{
O. HENRYK DAMIAN WOJTYSKA CP
}

\title{
POCZĄTKI KULTU I PROCESY KANONIZACYJNE SW. KAZIMIERZA
}

\section{STAN BADAN*}

Pierwsze usystematyzowane informacje o wszczęciu procesu kanonizacyjnego królewicza Kazimierza (zm. 4 III 1484 r.) pod wpływem rozwijającego się kultu jego osoby podał desygnowany przez papieża Leona $\mathrm{X}$ do przeprowadzenia dochodzenia informacyjnego legat papieski Zachariasz Ferreri, który po dokonaniu tych czynności w Wilnie jesienią 1520 r., opisał je w dziełku zatytułowanym Vita Beati Casimiri Confessoris ex Serenissimis Poloniae Regibus et Magnis Lithuaniae Ducibus clarissimi, wydanym w Krakowie latem $1521 \mathrm{r}^{1}{ }^{1} \mathrm{~W}$ drugiej części tego utworu, po opisaniu żywota Kazimierza, podaje Ferreri krótkie dane o cudach, kulcie i pierwszych staraniach o kanonizację; ta - według niego - miała stać się przedmiotem zabiegów dopiero po cudownym, przypisywanym interwencji Kazimierza, zwycięstwie dwutysięcznej armii polsko-litewskiej nad liczącą 60 tys. żołnierzy potęgą moskiewską. Cud ten, „nostra aetate inauditum”, miał się zdarzyć „anno su-

* W artykule zastosowano następujące skróty tytułów wydawnictw źródłowych:

AcTom - Acta Tomiciana [...], ed. T. Działyński, t. 1-8, Posnaniare $1852-1860$.

AnRom - Analecta Romana, ed. J. Korzeniowski, Kraków 1894 (SRP 15).

Hp - Hagiografia polska, wyd. R. Gustaw, t. 1-2, Poznań 1971.

KodKWil - Kodeks dyplomatyczny katedry $i$ diecezji wileńskiej, wyd. J. Fijałek - Wł. Semkowicz, t. 1, Wilno-Kraków 1938-1948.

MPH - Monumenta Poloniae Historica, t. 1-6, Lwów-Kraków 1864-1893.

PSB - Polski Stownik Biograficzny, t. $1 \mathrm{mn}$.

SRP - Scriptores rerum Polonicarum, t. $1 \mathrm{mn}$.

Theatrum - G. Swięcicki, Theatrum sancti Casimiri, in quo ipsius prosapia, vita, miracula et illustris pompa in solemni eiusdem apotheoseos instauratione proponuntur, Vilnae 1604.

Theiner - Vetera monumenta Poloniae et Lithuaniae [...], ed A. Theiner, t. 1-2, Romae 1860-1861.

Vita - Z. Ferreri, Vita beati Casimiri confessoris ex serenissimis Poloniae regibus et magnis Lithuaniae ducibus clarissimi, Cracoviae 1521.

${ }^{1}$ Dziełko to, liczące 28 kart nie liczbowanych, nie ma ani daty, ani miejsca wydania. Estreicher twierdzi, że było tylko wydanie krakowskie, prawdopodobnie u F. Unglera; natomiast R. Gustaw uważa, że Vita była drukowana także w Toruniu (Hp 1 s. 748). 
periore" 2. Datacja ta, odczytana przez późniejszych badaczy jako rok rozpoczęcia starań o kanonizację, jest pierwszym i głównym powodem nieporozumień i błędów historiografii Kazimierzowego procesu. Jest rzeczą niemal pewną, że Ferreri (który w dalszym szczegółowym opisie wydarzeń i wykonanych przez siebie czynności jest świadkiem całkowicie wiarygodnym), nie znający szczegółów toczącej się od 1492 r. wojny z Moskwą, a przy tym piszący swą relację $\mathrm{w}$ pośpiechu, sprawę zagmatwał.

Nie przyczynił się do jej rozjaśnienia następny historiograf kultu i procesu Swiętego, kanonik wileński Grzegorz Święcicki. Był on delegatem biskupa i kapituły wileńskiej oraz króla Zygmunta III Wazy do Rzymu w sprawie kanonizacji w r. 1602. W dziele Theatrum Sancti Casimiri, in quo ipsius prosapia, vita, miracula et illustris pompa in solemni eiusdem apotheoseos instauratione proponuntur, wydanym $\mathrm{w}$ Wilnie w r. 1604, przepisał po prostu żywot Królewicza ułożony przez Ferreriego i załączył do niego opis cudów zdziałanych za wstawiennictwem Swiętego już w swoich czasach, oprócz dwóch, które miały się zdarzyć jeszcze przed r. 1520: pierwszy z nich to wskrzeszenie, wkrótce po śmierci Kazimierza (jak się należy domyślać), zmarłej dziewczynki imieniem Urszula; drugi zaś to wspomniane przez Ferreriego zwycięstwo nad Moskalami, z tym że Swięcicki poszerza partię dotyczącą jego antecedensów i wymienia już datę roczną - $1518^{3}$.

Cytowane przez niego w opisie tego cudu kroniki Miechowity, Decjusza, Wapowskiego i Kromera oraz własna wersja wydarzeń, jakie miały miejsce po śmierci Kazimierza, zawarta w długiej mowie ${ }^{4}$, wygłoszonej przezeń na „pokanonizacyjnej” uroczystości w Wilnie w r. 1604, dowodzą, że Swięcicki, pragnąc ubogacić opisy Ferreriusza i uściślić je przy pomocy innych współczesnych źródeł, skojarzył Ferreriuszowy opis zwycięstwa nad Moskalami z podaną przez Bernarda Wapowskiego (chociaż go wprost nie wymienia) wiadomością o cudownej odsieczy Połocka (27 VII 1518 r.), w czasie której Janowi Boratyńskiemu, wodzowi wojsk polskich, miał się ukazać św. Kazimierz, wskazując miejsce, w którym wojsko miało się przeprawić na drugi brzeg Dźwiny ${ }^{5}$. Relacja Wapowskiego była jednak tak różna w szczegółach od opisu Ferreriego, że Święcicki uznał to zwycięstwo za zupełnie inne niż opisane przez nuncjusza i potraktował je - poza skojarzeniem dat - jako drugi cud Kazimierzowy, przydając po drodze także i zwycięstwu z relacji Ferreriego cu-

2 Vita, k. A8r.

s Theatrum, s. 8-10.

${ }_{4}$ Tamże, s. $57-66$.

5 Zob. Kroniki Bernarda Wapowskiego $z$ Radochonic, kantora krakowskiego część ostatnia, czasy podługoszowe obejmująca (1480-1535). Wyd. J. Szujski, Kraków 1874 (SRP 2), s. 156. 
downe ukazanie się Swiętego ${ }^{6}$. Przybyło więc cudów ${ }^{7}$, potwierdziła się data rozpoczęcia starań o kanonizację w r. 1518.

Święcicki w swej mowie wprowadza jeszcze jeden ważny dla późniejszych badań epizod; twierdzi mianowicie, że po zakończeniu przez Ferreriego akt procesu do Rzymu sprawą jego dokończenia zajął się z polecenie króla Zygmunta Starego biskup płocki Erazm Ciołek. Na jego prośbę Leon X „Casimirum solemni ritu celestium cathalogo civium ascripsit”, a bullę kanonizacyjną przekazał posłowi. Tak więc „sprawa została zakończona”. W Polsce - jak twierdzi Święcicki - „oczekiwano tylko upragnionego powrotu" Ciołka. Ale ten zmarł zaraz potem w Rzymie na zarazę i razem z nim zaginęly jedyne świadectwa tego aktu: bulla papieska oraz pozostałe dokumenty ${ }^{8}$.

Do dzisiaj nie udało się ustalić, skąd Swwięcicki tę wiadomość zaczerpnął. Nie jest ona całkiem bezpodstawna, ponieważ okoliczności śmierci Ciołka w Rzymie w r. 1522 i losy jego spuścizny były faktycznie takie, jak je nasz autor przedstawił ${ }^{\ominus}$. W każdym razie, to nieszczęśliwe wydarzenie miało - według Święcickiego - spowodować, że od tej pory kult Swiętego ,abolitus prope oblivione fuerit”, aż do czasu wznowienia go przez króla Zygmunta III Wazę i biskupa wileńskiego Benedykta Woynę, którzy w r. 1602 uzyskali od papieża Klemensa VIII bullę zatwierdzającą kanonizację dokonaną przez Leona $\mathrm{X}^{10}$. Tekst tej bulli oraz opis uroczystości, jakie miały miejsce w Wilnie w maju 1604 r. w związku z jej publikacją, zajmują pozostałą część dzieła Swięcickiego ${ }^{11}$. W sumie jednak jego relacja o tym trzecim, definitywnym już etapie starań o kanonizację Królewicza rodzi wcale nie mniej wątpliwości niż wcześniejsze opisy rozpoczęcia tychże starań i kanonizacji za Leona X.

Ustalenia Swięcickiego zostały przez późniejszą historiografię bezkrytycznie przyjęte. Bollandyści przedrukowali „Żywot” Ferreriego i "Cuda" Swięcickiego, wprowadzając do nich jedynie niewielkie uzupełnienia, zaczerpnięte ze współczesnych żywotów Kazimierza, napisanych przez jezuitów polskich, zwłaszcza Piotra Skargę i Kazimierza Wijuk-Kojałowicza ${ }^{12}$. Potem sprawą kultu i procesu Królewicza nie intereso-

- Zob. Theatrum, s. $62-63$.

7 Swięcicki - tej samej mowie wskazuje ma jeszcze trzeci cud, który miał miejsce zaraz po zgonie Królewicza w r. 1484, kiedy to został poskromiony wichrzyciel i gwałtownik Krzysztof Szafraniec (tamże, s. 62). Autor wykorzystał tu dla odmiany przekaz kroniki Kromera, który zaraz po partii odnoszącej się do Kazimierza opisal sprawe Szafrańca. Zob. M. K romer, Kronika polska, t. 3, Sanok 1868 (tlumaczenie M. Błażewskiego), s. 1299.

8 Theatrum, s. 64. s. 195 .

2 Zob. H. Folwarski, Erazm Ciołek, biskup i dyplomata, Warszawa 1935,

10 Zob. Oratio Svencicii, [w:] Theatrum, s. $64-65$.

11 Tekst bulli w Theatrum (s. 25-26).

12 Acta Sanctorum Martii, t. 1, Parisiis 1865, s. 349-354 (pierwsze wydanie Bollandusa id innych w Antwerpii 1663). 
wano się w ogóle aż do roku 1858, kiedy ukazało się w Wilnie dzieło A. Lipnickiego, zatytułowane: Życie, cuda i cześć sw. Kazimierza ${ }^{18}$. Autor nie wnosi w zasadzie wiele nowego do opisów Ferreriego, Swięcickiego i bollandystów, ale po raz pierwszy zajmuje się oceną źródeł ${ }^{14}$, uzupełnia dotychczas znane bardzo ważną dla ustalenia początków kultu Kazimierza bullą odpustową papieża Aleksandra VI dla kaplicy Królewicza $(1501)^{15}$ i poświęca - jako pierwszy historiograf Swiętego - cały rozdział pracy "sprawie kanonizacji" ${ }^{16}$.

Znaki zapytania pozostały więc nadal bardzo liczne, a żywotopisarze Swiętego, skoncentrowani na propagowaniu kultu, zupełnie nie zwrócili uwagi na nowe materiały źródłowe, które w tym czasie zostały opublikowane przez A. Theinera (Vetera monumenta Poloniae et Magni Ducatus Lithuaniae), T. Działyńskiego (Acta Tomiciana), J. Korzeniowskiego (Analecta Romana), J. Kurczewskiego (streszczenia akt kapituły wileńskiej) i H. Zeissberga (testament abpa J. Easkiego) ${ }^{17}$. Nie znał ich pierwszy krytyczny hagiograf Kazimierza Fryderyk Papée, który w doskonałym studium pt. Swięty Kazimierz ${ }^{18}$ oraz w kilkakrotnie wydawanym jego żywocie ${ }^{19}$ wyjaśnił wiele faktów dotyczących życia Królewicza i wyrwał tę ,postać historyczną z mgły legendarnej ascezy", w: jaką przenosił go Ferreri ${ }^{20}$. Jednakże procesem samej kanonizacji wolał się nie zajmować. Nadmienił tylko, że akt z r. 1521 (uznaje więc, że Rzym wypowiedział się jednak w r. 1521) był beatyfikacją Kazimierza, a w roku 1602 miała miejsce jego kanonizacja ${ }^{21}$. Nowy element, który dodatkowo skomplikował sprawę.

Dopiero w r. 1924 ks. Jan Fijałek znacznie pchnął naprzód badania nad kultem i procesami kanonizacyjnymi św. Kazimierza. W artykule zatytułowanym: Cześć św. Kazimierza i cerkwie ruskie $w$ Wilnie ${ }^{22}$ poddaje on w zasadzie analizie krytycznej tylko twierdzenie Ferreriego o rzekomej wrogości Kazimierza wobec prawosławia, ale przy okazji, wykorzystując wzmiankowaną już bullę Aleksandra VI z r. 1501 oraz nie znane dotąd teksty, jak: wiersz Andrzeja Krzyckiego z r. $1513^{28}$, testa-

18 Drugie wydanie: Wilno 1907.

14 Tamże, s. $315-319$.

15 Tamże, s. 139 i $304-306$.

16 Tamże, s. $139-155$.

17 Publikacje te będą wykorzystane niżej.

$18 \mathrm{~W}$ : Studya $i$ szkice $z$ czasów Kazimierza Jagiellończyka, Warszawa 1907, s. $141-154$

19 F. Papée, Sw. Kazimierz królewicz polski; 1 wyd. Lwów 1902, 3 wyd. Lwów 1933.

20 Zob. F. Pa pée, Studya, s. 145.

21 Tamże, s. 153.

22 Stanowi on częśc obszerniejszej rozprawy pt.: Opisy Wilna aż do potowy XVII w. Cz. 2, „Ateneum Wileńskie” 2 (1924) s. 131-158.

23 Zob. A. Krzycki, Carmina. Ed. C. Morawski, Cracoviae 1888, s. 53-56. 
ment abpa Jana Easkiego ${ }^{24}$ i instrukcję królewską dla posła polskiego do Rzymu Jana Wilamowskiego z r. $1539^{25}$, podważa po raz pierwszy możliwość dokończenia procesu Ferreriego w Rzymie i akt kanonizacji w r. $1521^{26}$. Udowadnia także niezbicie, że skojarzenie cudownego zwycięstwa $\mathrm{z}$ opisu Ferreriego $\mathrm{z}$ odsieczą Połocka w r. 1518 jest dziełem historiografii późniejszej; błądzi natomiast twierdząc, że pierwszym, który te dwa „cudowne" zwycięstwa od siebie oddzielił, był Piotr Skarga ${ }^{27}$; nie wyklucza jednak ani zasadniczej prawdziwości opisu Ferreriego w tej sprawie (według niego mogło mieć miejsce jakieś zwycięstwo tego rodzaju w r. 1519), ani modłów zanoszonych do Kazimierza przed bitwą ${ }^{28}$. Nie interesują natomiast Fijałka początki starań o kanonizację Królewicza.

Po Fijałku obserwujemy $w$ badaniach tego zagadnienia na terenie Polski całkowity zastój, a nawet regres, skoro jeszcze w r. 1966 Karol Górski, opierając się na dawnych danych, postawił twierdzenie, że kult Swiętego zaczął szerzyć nie kto inny jak możnowładztwo litewskie, i to dopiero po odsieczy Połocka w r. 1518, oraz że był On jednak kanonizowany w r. 1521, po czym akta Jego kanonizacji zaginęły ${ }^{29}$. Powtórzył te twierdzenia ks. Henryk Rybuis w biogramie św. Kazimierza, zamieszczonym w r. 1970 w Hagiografii polskiej, pomimo że znał także fakt rozpoczęcia starań o kanonizację w r. 1514 (nieznany dokument znajdujący się dzisiaj $\mathrm{w}$ archiwum klarysek $\mathrm{w}$ Krakowie) ${ }^{30}$. Podaje on ponadto dosyć dużo faktów dotyczących procesu przeprowadzonego w Wilnie przez Ferreriego, ale nie są to relacje wolne od błędów ${ }^{31}$.

Pokłosiem zaniedbań historiografii polskiej w sprawie kanonizacji św. Kazimierza są wywody Marcelego Kosmana, który jeszcze w r. 1976 w swych Drogach zaniku pogaństwa u Battów, poza swoistym wykorzystaniem sumy starych błędnych twierdzeń, dorzucił jeszcze swoje, niczym nie poparte rozwiązania zagadnień spornych, twierdząc m. in. (wcale nie za F. Papée, którego nie cytuje), że w r. 1521 nastąpiła beatyfikacja Kazimierza, a w 1601 - kanonizacja. Dowodzi tego z faktu, że „tutułu divus przed 1521 r. Kazimierz nie posiadał" ${ }^{32}$. Jest to stwierdzenie zupełnie

\footnotetext{
${ }^{24}$ Zob. H. Z eis s berg, Johannes Easki, Erzbischof von Gnesen (1510-1531) und sein Testament, „Sitzungsberichte der Phil.- Historische Classe der Kaiserlichen Akademie zu Wien" 77 (1874).

25 Zob. J. Fijałek, Opisy Wilna, s. 149 (przedruk odnośnego fragmentu z rękopisu Biblioteki Czartoryskich w Krakowie).

26 Tamże, s. $134,148-149$.

${ }_{27}$ Tamże, s. 153. Wiemy, że pierwszym, który je rozróżnił, był G. Swięcicki (zob. wyżej przypis 6).

28 J. Fi jałek, Opisy Wilna, s. 153.

29 Zob. biogram św. Kazimierza w: PSB 12 s. 287.

30 Rkps 36 B (dawna sygn. 307) s. $249-253$. Stanowi on załącznik do akt procesu kanonizacyjnego bł. Kingi (zob. niżej przypis $n r$ 108).

${ }^{81} \mathrm{Hp} 1$ s. $744-747$.

32 M. Kosman, Drogi zaniku pogaństwa u Battów, Warszawa 1976, s. 152; cały wywód na s. 148-152.
} 
arbitralne, ponieważ tytuł ten był dawany Królewiczowi już przynajmniej od r. 1502, o czym piszą nawet cytowani przez Kosmana tacy autorzy, jak Fijałek i Ivinskis.

Lepszymi torami potoczyły się powojenne badania historyków litewskich, piszących na emigracji. Zenonas Ivinskis, autor najlepszego niewątpliwie do tej pory naukowego życiorysu Swiętego ${ }^{33}$, powtarza wprawdzie jeszcze w r. 1955 niektóre stare opinie o losach Kazimierzowego procesu kanonizacyjnego, ale wykorzyistuje także nowe źródła, które sam odkrył, czy to w nieznanych do tej pory hagiografom drukach (Vetera monumenta, streszczenia akt kapituły wileńskiej), czy wprost w Archiwum Watykańskim (np. cytowany niżej list ces. Maksymiliana I do pap. Leona $\mathrm{X}$ w sprawie kanonizacji Kazimierza w r. 1517) ${ }^{34}$.

Dane zgromadzone przez Ivinskisa stały się punktem wyjścia do dalszych badań podjętych $\mathrm{z}$ okazji 500. rocznicy urodzin Kazimierza przez Pawła Rabikauskasa SJ i Jonasa Matusasa. Obydwaj oni poświęcili temu zagadnieniu specjalne artykuły opublikowane w litewskim roczniku naukowym „Aidai”, ukazującym się w Stanach Zjednoczonych ${ }^{35}$. Rabikauskas zebrał ponadto i podsumował te ustalenia $\mathrm{w}$ obszernym biogramie Swiętego, wydrukowanym w „Bibliotheca Sanctorum” w r. $1963^{36}$. Wynika z nich, że autorzy litewscy znają bullę odpustową Aleksandra VI z r. 1501 i trochę nowych dokumentów watykańskich, zarówno drukowanych, jak i przez nich samych odkrytych. Dzięki nim Rabikauskas ustala, że proces kanonizacyjny Kazimierza został oficjalnie zapoczątkowany 4 XI 1517 r., że kanonizacji w r. 1521 nie było i że wobec tego w r. 1602 mamy do czynienia z tzw. kanonizacją równoznaczną (aequipollens) ${ }^{37}$.

Ostatnie - jak dotąd - słowo na temat najwcześniejszych przejawów kultu Swiętego i starań o Jego kanonizację, podsumowując badania polskie i litewskie, powiedział ks. Florian Niewiero w obszernym artykule pt. Dzieje kultu św. Kazimierza $w$ kraju $i$ za granica, opublikowanym w r. 1970 w „Naszej Przeszłości” ${ }^{38}$. W paragrafie Kanonizacja $s w$. Kazimierza ${ }^{39}$ zebrał on niemal wszystko, co do tej pory w tej sprawie napisano (nie zna jedynie prac Rabikauskasa i Matusasa) i uzupełnił własnymi kwerendami źródeł drukowanych. W oparciu o tę dokumentację

33 Sventasis Kazimieras 1458-1484, New York 1955.

34 Tamże, s. 58-59, 67.

35 Zob. P. Rabikauskas, Pastabo prie šv. Kazimiero garbinimo istorijos [Uwagi o historii kultu św. Kazimierza], „Aidai” 1958, s. 305-311; J. M a tus a s, Del šv. Kazimiero kanonizavimo ir lietuviškumo [W sprawie kanonizacji i litewskości św. Kazimierza], „Aidai” 1959, s. 252-257.

${ }_{36}$ T. 3 kol. 895-906 "(dobra dokumentacja ikonograficzna).

37 Tamże, kol. 896-900.

3833 (1970) s. $61-124$.

39 Tamże, s. 78-91. 
rozstrzygnął definitywnie, zestawiając argumenty za i przeciw, że kanonizacji w r. 1521 nie było ${ }^{40}$ i że przed procesem kanonizacyjnym, przeprowadzonym w Wilnie w r. 1520 przez Ferreriego, był wcześniej. (w r. 1518) przeprowadzony tamże inny - przez abpa Jana Łaskiego ${ }^{41}$. Jeśli jednak idzie o ich zapoczątkowanie, to niewiedza o odkryciu dokumentu z r. 1514, przeoczenie kilku listów w Acta Tomiciana i źle odczytana datacja trzech listów wydanych przez Theinera ${ }^{42}$, obok kilku innych drobnych potknięć interpretacyjnych ${ }^{48}$, spowodowały, że postawił tezę o rozpoczęciu starań o kanonizację Kazimierza przed Stolicą Apostolską przez stronę polską dopiero w r. 1516 i nieco pogmatwał chronologię wydarzeń. Dał jednak w sumie bardzo bogaty zestaw źródeł i opracowań, które ujęte metodycznie znacznie posunęły badania nad Kazimierzowym kultem i procesami kanonizacyjnymi ${ }^{44}$.

Niniejsze studium jest próbą szczegółowej analizy i uporządkowania znanych źródeł, uzupełnionych nowymi, które udało się odkryć. Konsekwencją tego założenia jest maksymalne wykorzystanie w korpusie pracy analizowanych tekstów, by można je było ze sobą porównać i z ich sformułowań wyczytać to, czego historiografowie procesów św. Kazimierza nie zdołali na podstawie zebranej dotąd dokumentacji ustalić.

\section{PROCESY KANONIZACYJNE W POCZAZTKU XVI W.}

Wątpliwości, jakie zrodziły isię w wyniku zestawienia dotychczasowych badań nad kultem i procesami św. Kazimierza, prowokują najpierw do ustalenia, jak wówczas rozumiano beatyfikację i kanonizację i z jakich elementów składał się sam proces kanonizacyjny. Po pierwsze: przed r. 1634, tj. przed oficjalnym rozróżnieniem przez papieża Urbana VIII kultu antycypowanego i kultu uznanego, nie ma mowy o dwu różnych aktach Stolicy Apostolskiej, z których jeden byłby nazwany beatyfikacją, a drugi kanonizacją. Do tego czasu (a faktycznie do r. 1662, kiedy Aleksander VII zastrzegł Stolicy Apostolskiej uroczyste ogłaszanie beatyfikacji) istniała w praktyce Kościoła Rzymskiego tylko kanonizacja, za-

40 Tamże, s. $79,82-86$.

41 Tamże, s. 82 (za J. Fijałkiem).

42 Zob. niżej przypisy: 90, 106, 107, 123.

${ }^{43} \mathrm{M}$. in. odnośnie do składu trybunału kanonizacyjnego w r. 1520 (zob. przypis 176), autorstwa listu postulacyjnego z 18 II 1516 r. (zob. przypis 128), inicjatora wznowienia starań o kanonizację w r. 1600 (zob. przypis 225), określenia wartości bulli Klemensa VIII jako „kanonizacyjnej” (przypis 246) oraz czasu pobytu Ferreriego w Wilnie półtora roku (F. N i ewi e ro, jw., s. 82).

${ }_{44}$ Bardzo sumarycznie przedstawił stan badań na temat św. Kazimierza ks. T. Krahel w swej książce: Historiografia (archi)diecezji wileńskiej do 1939 roku, Warszawa 1979, s. 126-128. Jego zasługą jest zwrócenie uwagi na badania litewskie.

13 - Analecta Cracoviensia 
rezerwowana od początku XIII w. dla Stolicy Apostolskiej ${ }^{45}$. Jest oczywiste jednak, że zanim ją sfinalizowano, kandydat na ołtarze odbierał kult i obdarzono go - tak wynika przynajmniej $\mathrm{z}$ dokumentów XV i XVI w. - tytułem „błogosławiony”, zdecydowanie już w tych wiekach odróżnianym od tytułu „święty”. Trudno jest przy obecnym stanie badań nad tym zagadnieniem " ustalić, jak dalece był ten kult kontrolowany i czy istniała wtedy jakaś instancja regulująca używanie tytułów „beatus" i "divus". Historycy prawa kościelnego dają w tym względzie dwie, niekoniecznie wykluczające się hipotezy. Jedni twierdzą, że po definitywnym zarezerwowaniu kanonizacji Stolicy Apostolskiej przez papieża Grzegorza IX w r. $1234^{47}$, biskupi nie przestali zatwierdzać kultu publicznego sług bożych w swych diecezjach i stąd zrodziło się rozróżnienie beatyfikacji, zarezerwowanej ordynariuszowi miejsca lub synodom prowincjonalnym, i kanonizacji, którą mógł ogłaszać tylko papież ${ }^{48}$. Nie są jednak w stanie podać, na czym taka beatyfikacja polegała. Czy było to tylko zwykłe oświadczenie, że sługę bożego wolno już odtąd nazywać błogosławionym, czy może dokonywano - na wzór dawnych kanonizacji lokalnych - podniesienia relikwii zmarłego i przeniesienia ich do specjalnie poświęconego mu kościoła lub kaplicy? Nie wiadomo.

Inni kanoniści wiążą ,historyczne początki beatyfikacji z faktem rozpoczęcia procesu kanonizacyjnego lub istnienia bardzo żywego kultu ludowego, zmierzającego do kanonizacji" "49. Innymi słowy oznaczałoby to, że kandydat na ołtarze mógł być obdarzony tytułem błogosławionego albo od momentu oficjalnego rozpoczęcia procesu, albo jeszcze wcześniej, jeśli cieszył się wielkim kultem, w wyniku którego zamierzano podjąć starania o jego kanonizację. Kto jednak w tym ostatnim przypadku decydował o nadaniu takiego tytułu - biskup czy papież - autorzy nie ustalają. Wiaảomo jedynie, że zarezerwowanie Stolicy Apostolskiej wyłącznego prawa do określania, w jakich przypadkach wolno go używać, miało

45 Zab. J. Löw, Beatificazione, [w:] Enciclopedia Cattolica, t. 2. Città del Vaticano 1949, kol. 1097.

46 Nie istnieje właściwie do dzisiaj żadna praca na temat stosunku Kościoła do kultu sług Bożych przed ich kanonizacją, w okresie od jej zarezerowania Stolicy Apostolskiej w XIII w. do wprowadzenia beatyfikacji papieskiej w XVII w. M. $\mathrm{Machejek} \mathrm{i}$ W. Padacz, mówiąc io procesach na terenie diecezji, używają dla tego okresu pojęc ,beatyfikacji" i ,kanonizacji” zupelnie zamiennie (zob. Sprawy beatyfikacyjne na terenie diecezji, Poznań 1957, s. 12-13, 18-19, 142-143). Wiele błędów i niejasności jest $\mathrm{w}$ obszernym artykule $\mathrm{R}$. Naza w Dictionnaire du Droit Canonique, t. 3, Paris 1942, kol. 12. Najobszerniej i najlepiej problem został przedstawiony w wyżej cytowanym artykule J. Löwa.

${ }_{47} \mathrm{Nie}$ przez Aleksandra III w r. 1181, jak sądzono dotychczas. Zob. S. Kuttner, La réserve papale du droit de canonisation, "Revue historique de droit français et étranger" (Serie 4) 17 (1938) s. 172-228.

${ }_{48}$ Zob. M. Eckardt, Seligsprechung, [w:] Lexicon für Theologie und Kirche, Bd. 9, Freiburg im Br. 1964, kol. 642; i za nim J. Z u be k, Beatyfikacja, [w:] Encyklopedia katolicka, t. 2, Lublin 1976, kol. 164.

49 J. L ö w, Beatificazione, kol. 1096. 
miejsce dopiero w r. 1606, kiedy papież Paweł V zgodził się, by po rozpoczęciu procesu kanonizacyjnego Salwatora da Orta, ów „interim beatus nuncupetur" so.

Nie przesądzając, która $\mathrm{z}$ hipotez bardziej odpowiada badaczowi kultu i procesów kanonizacyjnych św. Kazimierza, pastaramy się niżej przedstawić fakty dotyczące Jego sprawy. Wydaje się, że magą one nieco to zagadnienie rozjaśnić. Jedno jest wszakże pewne: w świetle ówczesnej procedury kanonizacyjnej nie może być mowy o jakimś procesie beatyfikacyjnym i beatyfikacji Królewicza w dzisiejszym tego słowa znaczeniu. Jeśli $\mathrm{w}$ dokumentach jest mowa o staraniach podejmowanych w Stolicy Apostolskiej o wyniesienie Go na ołtarze, są to starania o kanonizację.

Przekazy historyczne o samym procesie kanonizacyjnym w tamtych czasach są dostatecznie liczne i pozwalają wyrobić sobie o nim całkiem pewne zdanie. W głównych zrębach ukształtował się on już w średniowieczu, gdy papieże - po zarezerwowaniu sobie kanonizacji - nie zadowalając się materiałem dowodowym, który przedkładali im biskupi, zaczęli wysyłać do miejsc spoczynku i kultu sług bożych swoich delegatów $\mathrm{z}$ odpowiednimi upoważnieniami (intimationes), aby jako trybunał delegowany przesłuchiwali tam świadków naocznych, wiarygodnych i zaprzysiężonych ${ }^{51}$. Kanoniści ustalają na podstawie zachowanych akt takich dochodzeń $w$ diecezjach, że także w okresie późniejszym postępowanie takiego trybunału delegowanego obejmowało: (1) sprawdzenie opinii o świętości, (2) poznanie życia i cnót (sporządzenie autentycznego życiorysu), (3) przesłuchanie świadków odnośnie do cudów, (4) rozpoznanie zwłok (otwarcie grobu) ${ }^{52}$.

Takie dochodzenie in partibus, tzn. poza Rzymem, było częścią pełnej procedury kanonizacyjnej in Curia Romana, ukształtowanej zasadniczo w ciągu XIII w. i opracowanej następnie szczegółowo przez kanonistów XIV w., zwłaszcza Jana Andrzejowego (Joannes Andreae, profesor prawa kościelnego na uniwersytecie bolońskim, zm. 1348). Jej dokładny opis, sporządzony na podstawie praktyki Kościoła, pozostawił kard. Jakub Gaetani (zm. po 1352). Procedurę tę odnajdujemy realizowaną w całej rozciągłości w XV i XVI w.

$\mathrm{Na}$ poszczególnych etapach postępowania kanonizacyjnego wymagano więc w szczególności:

1. „Odczekać aż osoby uczciwe i godne zaufania doniosą papieżowi o fakcie [kultu] i zaczną prosić o przeprowadzenie kanonizacji świętego,

50 Tamże, kol. 1097.

51 Zob. H. Miszta l, Causae historicae $w$ postępowaniu beatyfikacyjnym $i k a-$ nonizacyjnym, Lublin 1981, s. 26.

32 Tamże, s. 23. 
i to nie tylko raz, ale przez ponawiane prośby [...] Nie zwykł bowiem ulegać prośbom od razu, lecz oczekuje, ażeby kołatano doń długo, i bada, jaka jest opinia i czy zabłyśnie cudami powtarzanymi ${ }^{58}$.

2. „Jeśli prośby są powtarzane i ustala się opinia o dokonywanych cudach, Najwyższy Pasterz zwykł przedstawiać sprawę braciom kardynałom" i za ich radę deleguje biskupa miejsca spoczynku sługi bożego lub „innych biskupów tego kraju, z którego pochodzi święty [...] ażeby dochodzili opinii świętości i nabożeństwa ludu i autentyczności cudów. Stwierdzone fakty powinni przesłać do niego, ale ogólnie gdy chodzi o cuda; co się zaś tyczy opinii świętości, to nie o tym, czy jest to opinia słuszna, ale tylko sam fakt jej istnienia i czy wydaje się im, że należy rozpocząc dochodzenia" ${ }^{54}$.

3. „Jeżeli odpiszą podając to, co widzieli i że należy wszcząć dochodzenie celem poznania prawdy, papież raz jeszcze szuka porady braci [kardynałów] i decyduje, czy dochodzenia należy rozpocząć, lub nie" ${ }^{55}$.

4. „Jeżeli wydaje mu się, że należy wszcząć dochodzenia, posyła jeszcze raz listy delegacyjne tym samym co poprzednio, lub innym. W listach znajdują się pytania: o opinii świętości, o życiu, o cudach. Mają oni rozpytywać $\mathrm{z}$ uwagą, wiernie i roztropnie, według artykułów i pytań, jakie im $\mathrm{w}$ bulli zostały przesłane, a to, o czym się dowiedzieli, mają odesłać pod pieczęciami" ${ }^{56}$.

5. „Po przesłaniu dokumentów do kurii, zbadanie ich poleca się kapelanom" - w początkach XVI w. audytorom roty rzymskiej - aby je przebadali i zaopiniowali, zwłaszcza co do sposobu przeprowadzania dochodzeń ${ }^{\mathrm{s}}$.

6. „Uwagi tak poczynione rozpatruje papież $\mathrm{z}$ wielką uwagą razem z braćmi" kardynałami i na sekretnym konsystorzu poleca trzem z nich: biskupowi, prezbyterowi i diakonowi, by wypowiedzieli się, co o sprawie kanonizacyjnej myślą ${ }^{58}$.

5s Joannes Andreae, In Decretales Commentaria, Venetiis 1581, s. 230. Tłumaczenie polskie zaczerpnięto z: J. Lis ow ski, Kanonizacja św. Stanisława $w$ świetle procedury kanonizacyjnej Koscioła dzisiaj $i$ dawniej, Rzym 1953, s. 121. Jest to jedno z najlepszych obecnie opracowań procesów historycznych, wykonane w celu rozjaśnienia zawiłości procedury procesowej kanonizacji św. Stanisława. 54 Joannes A ndreae (jw.) oraz opis card. Gaetaniego u Lisowskiego (s. $121,124)$.

55 Tamże, s. 121 ; por. s. 124.

56 Tamże, s. 121-122; por. s. 124.

57 Tamże, s. 122, 124. O spełnianiu tej funkcji przez audytorów roty zob.: AnRom s. 88; mówi o nich także Seweryn z Lubomla, opisując procedurę procesową zastosowaną przy kanonizacji św. Jacka w r. 1594 (Severinus Lubomlens is, De vita, miraculis et actis canonisationis Sancti Hyacinthi, Romae 1594, s. 156). Procedura ta zgadzała się we wszystkich elementach z referowaną tu procedura opisaną przez Jana Andreae (zob. tamże s. 155-156). Por. Z. O b e r t y ńs ki, Dzieje kanonizacji św. Jacka, „Prawo Kanoniczne” 4 (1961) z. 1-4 s. 79-172.

s8 $\mathrm{L}$ i s 0 w ski, jw., s. $122,124$. 
7. Jeśli opinie są pozytywne, na następnym konsystorzu sekretnym jeszcze raz poddaje się sprawę dyskusji, ocenia wiarygodność cudów i papież podejmuje decyzję o kanonizacji.

8. Decyzja ta jest logłaszana uroczyście na konsystorzu publicznym.

9. Sama uroczystość kanonizacyjna odbywa się $\mathrm{z}$ wielką pompa w kościele, specjalnie na ten cel wybranym przez papieża ${ }^{59}$.

Ten sposób przeprowadzania procesu był stosowany we wszystkich znanych kanonizacjach XV w., jak świadczą zachowane akta, m. in. procesu św. Katarzyny ze Sieny, kanonizowanej w r. $1461^{60}$. Zmiany, polegające głównie na uporządkowaniu procedury procesowej i rozdzieleniu procesów kanonizacyjnych i beatyfikacyjnych, wprowadził dopiero papież Urban VIII mocą bulli Coelestis Hierusalem z 5 VII 1634 r. ${ }^{61}$

To szczegółowe zrelacjonowanie postępowania kanonizacyjnego wydawało się konieczne dla wyjaśnienia wielu dotychczasowych nieporozumień $\mathrm{w}$ sprawie procesu św. Kazimierza; ma ono poza tym kapitalne znaczenie dla zrozumienia wielu faktów niezbyt jasno czytelnych w zachowanej dokumentacji.

\section{POCZĄTKI KULTU SW. KAZIMIERZA}

Najwcześniejsze świadectwa, zapisane zaraz po śmierci Królewicza, poparte opiniamil wypowiadanymi o nim za życia, wskazują ponad wszelką wątpliwość, że ich autorzy widzieli w Nim przede wszystkim ideał świętego władcy, odznaczającego się zwłaszcza mądrością i sprawiedliwością. Cnoty czystości i ascezy — zauważane wprawdzie już przez wcześniejszych świadków życia i kultu Kazimierza ${ }^{62}$ - zostały wypunktowane jako najważniejsze dopiero przez Ferreriego w r. 1520 i takimi już pozostały dla potomnych.

Głęboka religijność, zadziwiająca mądrość, samodzielnie (przy pomocy J. Długosza?) wypracowana i niezależna od ojcowskiej, a wręcz z nią sprzeczna koncepcja państwa federacyjnego (świadectwo pruskie) z władcą, który jest przede wszystkim stróżem sprawiedliwości (,,sprawiedliwość nad wszystko inne uprawiać winienem i pragnę" ${ }^{63}$ ), poparte dowodami w czasie regencji w Koronie w latach 1481-1483 sprawiły, że ból $\mathrm{z}$ powodu jego utraty wyraził się $\mathrm{w}$ świadczeniu o niespełnionych na-

59 Tamże, s. $124-125$.

${ }_{60} \mathrm{M}$ is z t a 1 , jw., s. $26-27$.

${ }_{61}$ Tamże, s. 33. Por. M a chejek, P a d a c z, Sprawy beatyfikacyjne, s. 18.

62 Zob. niżej swiadectwa kronikarza gdańskiego (przypis 67) i J. Vadianusa (przypis 78) oraz zapis Stanisława Gorskiego, zbieracza tomicjanów: „Casimirus, castissimus iuvenis, in virginitate mortuus est" (AcTom $1 \mathrm{~s} .13$ ).

${ }_{63}$ Fragment listu do Wrocławian (tłum. F. P a pé e, Studya s. 147). 
dziejach, jakie $\mathrm{z}$ jego osobą wiązano. Pisał o nim Filip Kallimach, że „powinien był się albo nie urodzić, albo pozostać wieczny" " Inni zareagowali na wieść o Jego śmierci mniej wzniosłymi, ale nie mniej wymownymi i oddającymi powszechne przekonanie świadectwami: kronikarz mansjonarzy kaplicy św. Krzyża na Wawelu nazwał go „młodzieńcem o wspaniałym charakterze, bardzo uczonym [...] miłośnikiem sprawiedliwości” "s; autor Spominek mieszanych określił go jako „,pełnego wymownych i świętych obyczajów oraz pobożnych czynów wobec swoich poddanych" "8; zaś gdański kronikarz tzw. „wojny popiej” donosił, że „był on bardzo mądry i cnotliwy, i rządził [w Polsce] na zlecenie króla dwa lata, a władca i lud bardzo go chwalili, za co niech Bóg okaże mu swoją łaskawość" ${ }^{07}$. To gdańskie świadectwo społecznej oceny cnót i postępowania Królewicza potwierdził na wieść o Jeg.o śmierci także sekretarz królewski Jan z Targowisk (biskup przemyski w latach 1485-1492); „Książę zadziwiającej cnoty i roztropności oraz wyjątkowej nauki, którymi zdobywał sobie miłość wielu ludów" "8s.

Centrum tej „atrakcji”, o której mówią jednogłośnie rozrzucone po całym państwie świadectwa, stał się zaraz po śmierci Kazimierza jego grób w katedrze wileńskiej, do którego wnet zaczęły pielgrzymować liczne rzesze wiernych, przekonanych o cudotwórczej mocy świątobliwego księcia. Ferreri, po wysłuchaniu świadków w r. 1520, pisze, że „wszechmogący Aktor, by dowieść jak wielkim u Niego jest Kazimierz mocą swych zasług i cnót, natychmiast raczył okazać przy jego grobie tyle i takich znaków i cudów [...] że nikt nie powinien wątpić o jego wiecznej szczęśliwości z Chrystusem w niebie. Nieuleczalnie chorzy, głusi, niemi, chromi, ślepi, skoro się tylko do jego grobu (mausoleo) zbliżą, odzyskują słuch, mowę, zdolność poruszania się, wzrok i dawne zdrowie, a nadto (co jest o wiele bardziej godne podziwu i prawie niewiarygodne) powracają do życia umarli" "9.

Prawdziwość tego topologicznego świadectwa kultu ludowego przy grobie Kazimierza potwierdzają źródła wcześniejsze. Najstarsze znajduje się w mowie obediencyjnej, którą w czasie uroczystego konsystorza wy-

64 F. P a pée, Studya, s. 151.

65 ,Adolescens optimae indolis, literatissimus, iustitiae amator" (Rocznik świętokrzyski, [w:] MPH 3 s. 87).

${ }_{66}$ „Plenus moribus disertis et sanctis ac piis operibus erga subditos suros" MPH 3 s. 231).

${ }_{67}$ „Er war seer klugk und sittigk, und hatte gerethe II jar geregireth, das der her konig im zcullies, und die herrschafft und die leutte sagten im gros lob nach. Got sey im gnedigk" (Danziger Chronik vom Pfaffenkriege, [w:] Scriptores rerum Prussicarum, t. 4. Hrsg. T. Hirsch, M. Töppen, E. Strehlke, Leipzig 1870 , s. 687).

${ }_{68}$ „Princeps stupendae virtutis et prudenciae ac doctrinae eximiae, quibus multorum populorum corda in sui amorem attraxerat" MPH 3 s. 237).

69 Vita, k. A6r-v. 
głosił w Rzymie 31 marca 1501 r. do papieża Aleksandra VI poseł wielkiego księcia litewskiego Aleksandra Jagiellończyka, jego sekretarz, zarazem prepozyt wileński - Erazm Ciołek, późniejszy biskup płocki. Mówiąc o synach króla Kazimierza, znów wrócił do niespełnionych nadziei wiązanych z naszym królewiczem: „zazdrosna śmierć porwała Kazimierza, młodzieńca ozdobionego nauką i wyjątkowymi zdolnościami oraz uczciwością życia, właśnie wtedy, kiedy miał pokazać jeszcze więcej"; ale dalej przechodzi do aktualiów: ,pochowany w głównym mieście księstwa, jaśnieje już prawie od 20 lat licznymi cudami, wstawiając się u Boga mocą swych cnót za każdym proszącym" ${ }^{70}$. Dwa miesiące później (15 maja 1501 r.) otrzymał Ciołek od tego samego papieża bullę odpustową dla kaplicy, w której był pochowany Kazimierz, „wsławiony tam - jak powiadają - licznymi cudami" "

O cudach tych słyszał także Maciej z Miechowa, obecny w Rzymie wtedy, kiedy przebywał tam Ciołek. W swej Kronice, do której materiały zbierał już od r. 1492 i którą w pierwszej redakcji ukończył jeszcze przed r. $1513^{72}$, pisze o Kazimierzu, że ,zdławiony suchotami, spoczywa pogrzebany w Wilnie, gdzie - jak wieśc niesie - błyszczy cudami z powodu świętości swego życia" ${ }^{73}$.

W pierwszych latach XVI w. świadkami kultu Kazimierza stają się także poeci. W r. 1511 ukazało się w Krakowie u Floriana Unglera zaczytane dziś „carmen elegiacum" De Divo Casimiro, regio Poloniae et Lithuaniae Principe, signis et miraculis clarissimo, ułożone przez studiującego wówczas w Akademii Krakowskiej, sławnego później poetę Rudolfa Agricolę ${ }^{74}$.

W r. 1513 nawiedził „błogosławiony grób” (busta beata) Królewicza w Wilnie poeta Andrzej Krzycki, wówczas kanclerz królowej Barbary. Znalazł przy nim liczne wota $\mathrm{z}$ wosku, składane przez czcicieli Kazimierza ${ }^{75}$, i sam oddał mu cześć, całując ze wzruszeniem trumnę, „której

70 „Casimirum, adolescentem profecto doctrina et excellenti ingenio ac vitae probitate ornatissimum mors invida, maiora parantem, surripuit. Qui in urbe Ducatus primaria sepultus, plurimis citra annos viginti claret miraculis, vota cuiuslibet suis apud Deum meritis commendans, ut neminem spe frustrari permittat" Theiner 2 s. 279).

71 Zob. KodKWil, 1 s. 575.

72 Zob. L. Hajdukiewicz, Maciej $z$ Miechowa, [w:] PSB 19 s. 30.

${ }^{73}$ "Casimirus, secundogenitus, ptisi praefocatus, in Vilna tumulatus requiescit. Et, ut fertur, pro sanctitate vitae miraculis coruscat" (Chronicon Polonorum, Cracoviae 1521, s. 327 - identyczne jak w pierwszym wydaniu z r. 1519; to samo powtórzone na s. 345).

${ }^{74}$ Dedykowany Pawkowi z Knosna. Wiadcmość o tym utworze zaczerpnął Estreicher z Janockiego. Zob. Bibliografia polska, t. 1, Kraków 1891, s. 76.

${ }^{75}$ Zab. ostatni wiersz jego Epitaphium na cześć Kazimierza „Adsta, te brevibus volo, viator [...]: „Haec vis cerea clariora dicet (A. K r z y ck i, Carmina, s. 56). Ks. Rybus przypisuje to epitafium Ferreriemu i za wydaniem w Acta Tomiciana (t. 3 s. 201) czyta: "Hec vis certa clariora dicet” (HP 1 s. 746), co nie daje sensu. Wydawca Carmina K. M orawski sądzi, że obok wosku były zawieszane na 
sława rozeszła się już po całym świecie, wieszcząc znaki zdumiewającej mocy" Sługi Bożego ${ }^{76}$.

Pierwsze głosy „ze świata” odezwały się wkrótce po Krzyckim, potwierdzając z Rzymu i Wiednia jego poetyckie relacje o rozpowszechnieniu się z Kazimierzowego kultu. Paweł Planca, adwokat konsystorialny, zajmujący się później sprawą kanonizacji Królewicza, pisał w styczniu 1515 r. do Zygmunta I o ,pobożności ludu” do tego Błogosławionego i o cudach, ,z których sam widział niektóre” w czasie wcześniejszej bytności $\mathrm{w}$ Polsce ${ }^{7 z}$. Zaś profesor uniwersytetu wiedeńskiego Joachim Vadianus (Watt), w przemówieniu wygłoszonym do Zygmunta Starego w czasie „kongresu królów” w Wiedniu w lipcu 1515 r., zaznacza, że Kazimierz „zmarł w takiej świętości życia, iż zaliczony w poczet błogosławionych, całą Lit'wę mnogością i wielkością swoich cudów in sui venerationem et cultum perrexit" ${ }^{78}$.

Przekonanie Vadianusa, że Kazimierz był ,in beatorum numerum relatus", jest potwierdzone później także przez Jodoka Ludwika Decjusza, który w księdze De Jagiellonorum Familia pisze, że Królewicz nie tylko „,jaśniał w tym wieku licznymi cudami”, ale także ,,in beatorum numerum relatus est" ${ }^{79}$. Obydwa te świadectwa zdają się sugerować jakiś wcześniejszy akt uznania jego kultu. Co więcej, takie przypuszczenie jest do pewnego stopnia potwierdzone przez jedno z najwcześniejszych świadectw, odkryty przez H. R. Zeissberga traktat z r. 1502 o wychowaniu królewskiego dziecka; autor wkłada w usta królowej Elżbiety, matki Króle-

grobie Kazimierza także jakieś obrazy, nie ma jednak na to dowodów (Carmina s. 56). Natomiast $\mathrm{N}$ i ewiero (jw., s. 80), próbując prawdopodobnie zrozumieć lekture Rybusa, twierdzi, że to wlaśnie sam tekst wiersza Krzyckiego został przez niego zlożony jako wotum na grobie Królewicza. O tym, że był to na pewno wosk, poświadczają akta kapituły wileńskiej, przechowane w streszczeniu ks. J. K u rc zewskiego (Kościót zamkowy czyli katedra wileńska $w$ jej dziejowym, liturgicznym, architektonicznym i ekonomicznym rozwoju, t. 3, Wilno 1916, s. $10 \mathrm{~nm}$.). Błądzi jednak E. Ję drkiew i cz tłumacząc "cerea" Krzyckiego jako świece (zob. A. K r z y ck i, Poezje, Warszawa 1962, s. 43). Akta wskazują, że były to wota w postaci figurek, lub nawet brył woskowych, skoro je następnie sprzedawano.

$76,[\ldots]$ tua busta beata [...] quae iam fama

licet toto divulgavit in orbe,

virtutis referens signa stupendae tuae [...]

Ut te cerno lubens, supplex et pronus adoro

doque tibi multis oscula cum lacrymis".

Ad tumulum Divi Casimiri, fratris regii, salutatio in primo adventu Vilnam Andreae Cricii (tegoż, Carmina, s. 53-54).

77 ,Attentis meritis istius Beati et devotione populi ac miraculis, quorum aliqua vidii, et reius prosapie, prosequendum est negotium et bene sperandum" (AcTom 3. s. 323).

78 ,In perpetuo celibatu vitam castissimam duxit, nihilque habuit prius quam fidem, quam abstinentiam et iustitiam colere; ea tandem vitae sanctitate decessit, ut in beatorum numerum relatus, universam Lituaniam miraculorum suorum varietate et magnitudine in sui venerationem et cultum perrexit" (AcTom 3 s. 401).

${ }^{79}$ "Claruit in hac aetate multis miraculis". Dzieło Decjusza jest wydane razem z Chronicon Polonorum Miechowity z r. 1521 (zob. s. 48). 
wicza, stwierdzenie że „Kazimierza, ponieważ religii czciciel był szczególny, między błogosławionymi po śmierci potomność umieściła" ${ }^{80 . ~ C z y ~}$ taki akt mógł mieć i rzeczywiście miał miejsce jeszcze przed rokiem $1502 ?$

\section{PROBLEM DATY ROZPOCZĘCIA STARAÑ O KANONIZACJE I ICH MOTYWOW}

Dosyć liczne źródła dotyczące dziejów Wilna i katedry wileńskiej na przełomie XV i XVI w. nie wymieniają żadnego wydarzenia z takich, które można byłoby zakwalifikować jako publiczne uznanie kultu Kazimierza, a więc otwarcie grobu lub ogłoszenie, że od tej chwili wolno go czcić jako błogosławionego. Zwróćmy uwagę, że w wszystkich pochwałach pośmiertnych Królewicza aż do r. 1502 ani razu nie nazwano go „,beatus” lub „divus”. Określeń tych nie użył także Erazm Ciołek w laudacji wygłoszonej 31 marca 1501 r. przed papieżem Aleksandrem VI. Mowę tę zakończył jednak bardzo znamiennym oświadczeniem, że cuda zdziałane za przyczyną Kazimierza, „kiedyś razem zebrane, zostaną w większej liczbie przedstawione Stolicy Apostolskiej" ${ }^{81}$. Brzmi to jak zapowiedź rozpoczęcia starań o kanonizację. Dwa miesiące później (15 maja 1501 r.) sam papież wystawia bardzo charakterystyczny i zastanawiający dokument, po którym pojawiają się wspomniane wyżej stwierdzenia, że Kazimierz został wciągnięty na listę błogosławionych i regularnie już odtąd jego imię poprzedzane jest tytułami „divus" lub ,beatus”. Dokumentem tym jest bulla, mocą której Aleksandr VI udziela 20 lat i 20 kwadragen odpustu tym wszystkim, którzy w dniu Bożego Narodzenia oraz w uroczystości Matki Bożej Gromnicznej i Wniebowziętej nawiedzą kaplicę, gdzie znajduje się ciało Kazimierza, i złożą ofiarę na jej utrzymanie $^{82}$. Wprawdzie odpust nie odnosi się do Królewicza - bo też odnosić go do kandydata na ołtarz nie było wolno - ale wydaje się, że wzmianka o nim i stwierdzenie, że w tej właśnie kaplicy jaśnieje on cudami, jest niedwuznacznym uznaniem przez Stolicę Apostolską jego kultu, równoznacznym z pozwoleniem na rozpoczęcie starań o kanonizację i na tytułowanie go błogosławionym. Jeśli tak rzeczywiście było, to casus Kazimierza potwierdza hipotezy tych kanonistów, którzy ów-

80 „Casimyrum [...] cum religionis cultor fuisset praecipuus, inter divos post mortem posteritas collocavit" (H. R. Z Zissberg, Kleinere Geschichtsquellen Polens im Mittelalter, „Archiv für österreichische Geschichte” 55, 1877, S. 103). F. P a pé e błędnie tłumaczy słowo „divus” jako „swięty” (Studya s. 153).

81, ,...] quae aliquando simul congesta, Sanctae Sedi declarabuntur cummulatius" (Theiner 2 s. 279).

82 Wydał ją J. Kurczewski (Kościól zamkowy, t. 3 s. 4-5) oraz J. Fijałek i W. Semkowicz KodKWil 1 s. 575). 
czesną nieformalną beatyfikację wiążą ze zgłoszeniem do Stolicy Apostolskiej zamiaru wszczęcia starań o kanonizację.

Zwróćmy uwagę, że owe ofiary odpustowe na utrzymanie kaplicy są w aktach kapituły wileńskiej (niestety, pierwsze zapiski o nich zachowały się dopiero z r. 1521) określane jako ofiary zbierane na kanonizację $\mathrm{Ka}$ zimierza i składały się przeważnie $\mathrm{z}$ wotów woskowych, których wymowę (,si spectare libet, pedemque sistis") tak mocno podkreślił w r. 1513 Andrzej Krzycki ${ }^{88}$.

Tak więc początki starań o kanonizację Kazimierza miałyby miejsce już w r. 1501, i to za przyczyną młodszego brata Kazimierzowego, wielkiego księcia litewskiego - Aleksandra Jagiellończyka. Papież w motywacji wyżej wymienionej bulli odpustowej zaznacza, że daje tę łaskę ze względu na szczególne umiłowanie kaplicy Kazimierzowej przez księ-

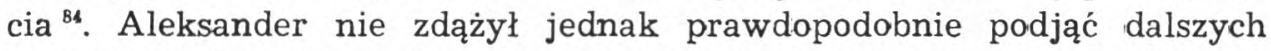
kroków w tym kierunku. Jeszcze tego samego roku, przed powrotem Ciołka z Rzymu, został królem polskim i musiał skoncentrować całą swoją działalność na obronie osłabionego państwa i rozwiązywaniu jego problemów wewnętrznych ${ }^{85}$. Umierając 19 sierpnia 1506 r., kazał się pochować „w kościele wileńskim, w kaplicy obok swego brata, błogosławionego Kazimierza" ${ }^{86}$.

Tak zakończył się pierwszy etap, nie tyle starań, co myśli o rozpoczęciu procesu kanonizacyjnego Kazimierza. Drugi, efektywny jest związany z rządami następnego, najmłodszego brata Swiętego, króla Zygmunta Starego (1506-1548). Początek i przebieg tych starań aż do przybycia nuncjusza Zachariasza Ferreri do Wilna w r. 1520 jest jednak przedstawiany przez dawną i współczesną historiografię tak niejasno, że należy mu poświęcić nieco więcej miejsca. Zacznijmy więc znów od Ferreriego, który jest głównym sprawcą tych niejasności. Według niego - jak już było sygnalizowane - bezpośrednim motywem podjęcia starań o kanonizację Królewicza było druzgocące zwycięstwo wojsk polsko-litewskich nad Moskalami, przypisane wstawiennictwu św. Kazimierza. Poprzedziła je wielka inwazja 60-tysięcznej armii moskiewskiej, która wywołała ogromne przerażenie ludności żyjącej na południowo-wschodnich rubieżach Litwy. „Litwini byli przekonani - pisze nuncjusz - że spotkało ich to nieszczęście ponieważ nie wywiązali się z obietnicy (wielokrotnie czynionej) wszczęcia starań u Stolicy Apostolskiej o umieszczenie błogosławionego Kazimierza, błyszczącego niezliczonymi cudami, w katalogu

88 Zob. Carmina, s. 56. Por. Kurczewski, jw., s. 10, 12, 17, 22, 23.

84 Zob. KodKWil 1 s. 575.

85 Zob. F. P a pé e, Aleksander Jagiellończyk, Kraków 1949, s. 42-106.

s6 $\mathrm{M}$ i e chowita, Chronicon Polonorum. Lectio varians edycji z r.1519. Wyd. J. Szujski w: SRP 2 s. 281. Por. P a ée, Aleksander Jagiellónczyk, s. 116. 
świętych" ${ }^{87}$. Modlili się więc do Niego, prosząc o pomoc w walce i obiecując na serio podjąć starania o kanonizację, jeśli im pomoże pokonać wroga. Po tym wojsko wyruszyło w pole i miało miejsce szczegółow. opisane przez Ferreriego zwycięstwo 2-tysięcznej armii polskiej nad nawałą Moskali. W jego wyniku miano prosić króla Zygmunta I ,aby wystąpił do Stolicy Apostolskiej z prośbą o jak najszybsze zaliczenie Kazimierza w poczet świętych wyznawców” ${ }^{88}$, co król wnet wykonał ,listownie i przez specjalnych posłów; arcybiskupa Jana Łaskiego, a potem także przez ówczesnego biskupa przemyskiego, obecnie zaś - Ferreri pisze w r. 1520 - poznańskiego i wicekanclerza" Piotra Tomickiego ${ }^{89}$.

Tyle Ferreri. Jeśli jest prawdą, że dopiero po tym zwycięstwie Zygmunt Stary podjął pierwsze starania u Stolicy Apostolskiej o kanonizację Kazimierza przez abpa Łaskiego, to w jaki sposób mogło się ono wydarzyć „anno superiore” (tj. w r. 1519, licząc datę pisania Vita na rok 1520), skoro wiemy dziś, że już 20 października 1514 r. tenże abp Łaski skierował do papieża Leona $\mathrm{X}$ w czasie trwania Piątego Soboru Laterańskiego pierwszą udokumentowaną petycję o kanonizację Królewicza? ${ }^{00}$. Dokument ten i liczne następne dowodzą, że jeśli w podjęciu starań o tę kanonizację rzeczywiście decydującą rolę odegrało jakieś zwycięstwo oręża polsko-litewskiego, to musiało ono mieć miejsce przed październikiem 1514 roku.

Ponieważ historiografia polska nie znała do tej pory jakiegoś ważnego zwycięstwa polskiego w roku 1519 - co więcej, wiadomo, że wielka kampania $\mathrm{z}$ lat $1517 / 18 \mathrm{z}$ udziałem króla była raczej nie udana ${ }^{91}$ — przeto sądzono, że Ferreri popełnił w swoim opisie błąd datacji, referując w nim faktycznie wielką inwazję wojsk moskiewskich na Litwę w 1512 r., upadek Smoleńska w lecie 1513 r. i jedną z najgłośniejszych w Europie bitew XVI w., pod Orszą (8 IX 1514 r.) ${ }^{22}$, po której rzeczywiście król rozpoczął starania o kanonizację brata ${ }^{93}$. Dziś, po odnalezieniu listu posła weneckiego w Budzie Wawrzyńca Orio do senatu Najjaśniejszej Rzeczypospolitej z 24 X 1519 r. ${ }^{\text {94 }}$, wiemy, że Ferreri opisuje w Vita prawdziwe

87 „Eamque calamitatem, quia Divum Casimirum innumeris coruscantem miraculis (ut saepius una decreverant) in sanctorum catalogum ab Apostolica Sede referri, pollicitamque operam non impenderant, eis accidisse arbitrati sunt" (Vita, k. A7r).

${ }^{88},[. .$.$] ut apud Sedem Apostolicam, quod idem Casimirus Sanctorum Confesso-$ rum numero absque prolixiori mora adscriberetur intercederet" (tamże, k. A7v). 89 Tamże, k. A8r.

90 Archiwum Klasztoru SS. Klarysek w Krakowie, rkps 36B (dawna sygn. 307) s. $249-253$.

${ }_{91}$ Zob. Z. W o jciechow ski, Zygmunt Stary (1506-1548), Warszawa 1946, s. $59-66$.

92 Zob. Zarys dziejów wojskowóści polskiej do roku 1864, t. 1, Warszawa 1965, s. 331-336; por. W o j c i e ch ow s ki, jw., s. 50 .

93 Opinię taką wyraziłem w czasie sympozjum o \$w. Kazimierzu w Krakowie w listopadzie $1982 \mathrm{r}$.

94 M. S a nut.o, I diarii, t. 28, Venezia 1890 , s. 59-60. 
a nieznane historiografii ojczystej zwycięstwo wojsk polskich nad Moskalami, a błądzi umieszczając (lub niezręcznie redagując) dopiero po nim rozpoczęcie starań o kanonizację Kazimierza.

Ta nowa dokumentacja oraz dokładna analiza i studium porównawcze źródeł pozwalają wreszcie ustawić w logiczny szereg 3 wydarzenia wojenne przytaczane przez Ferreriego, Wapowskiego i Święcickiego w związku z kultem i rozpoczęciem starań o kanonizację św. Kazimierza, potwierdzając jednocześnie ich prawdziwość. Są to: bitwa pod Orszą w r. 1514, odsiecz Połocka w r. 1518 i zwycięstwo opisane przez Ferreriego z 1519 r. O pierwszym i drugim z nich wspomina przelotem Ferreri w Vita S. Casimiri, twierdząc, że nieszczęśliwy najazd Moskali w r. 1518/19 spadł na Polskę i Litwę z powodu niewywiązania się z wielokrotnie czynionych ślubowań (,ut saepius una decreverant”) rozpoczęcia zabiegów o kanonizację Królewicza ${ }^{95}$. Swięcicki, komentując ten tekst, doszedł do logicznego wniosku, że jeśli były wcześniejsze nie wypełnione obietnice, to musiały być także wyproszone wtedy łaski. Nie ulega wątpliwości, że upatrywał w nich również jakieś zwycięstwa. Zidentyfikować je pozwoliły mu wyczytane w Kronice Marcina Bielskiego relacje Bernarda Wapowskiego o zwycięstwie pod Orszą i o odsieczy Połocka ${ }^{96}$.

Intuicja kanonika wileńskiego była słuszna. Jego twierdzenie bowiem, że po tym pierwszym zwycięstwie, „divinitus gestam”, którego nie opisuje w szczegółach, ,przesłano królowi jego opis razem z jeńcami moskiewskimi”, i że na wieść o nim „natychmiast udał się do przybytku świętego, aby podziękować Bogu i Kazimierzowi oraz obiecał na serio zająć się sprawą zaliczenia go w poczet świętych" ${ }^{97}$, znajduje potwierdzenie $\mathrm{w}$ dostępnej dokumentacji dotyczącej bitwy orszańskiej. Sam Wapowski poświęca w swojej Kronice dużo miejsca modłom dziękczynnym w Wilnie i mówi o jeńcach oraz poselstwie wysłanym we wrześniu 1514 r. przez króla do Rzymu, gdzie właśnie wtedy sam się znajdował w orszaku abpa Łaskiego i gdzie - na jego prośbę - wydał zbiór wierszy opiewających to zwycięstwo ${ }^{98}$.

Znamienne jest także to, co obecny wtedy przy królu legat papieski Jakub Piso pisze $\mathrm{w}$ swej relacji o powszechnym przekonaniu, że ,zdarzyło się ono nie bez wstawiennictwa Boskich Orędowników", ponieważ Zygmunt Stary ,przed bitwą kazał gorąco modlić się w świątyniach Wilna, a po zwycięstwie za nie dziękować” ${ }^{99}$. Osobisty udział króla w tych

95 Zob. niżej, przypis 87.

96 Zob. Oratio Svencicii, [w:] Theatrum, s. 62-63; por. W a powski, Kroniki, s. $119-122$ i 156.

97 Miracula S. Casimiri, [w:] Theatrum, s. 9 Przedruk w Acta Sanctorum Martii, t. 1 s. 350 .

${ }_{98}$ Zob. jego Kroniki (s. 119-122) oraz Panegyris, wydany przez J. Szujskiego w załączeniu do Kroniki w 2 s. 347.

${ }_{99}$ "Certe fateri necesse sit, haec sine Divorum numine non evenisse, cum alioqui 
modłach potwierdza inny współczesny świadek - Maciej z Miechowa ${ }^{100}$. Jest oczywiste, że miejscem, w którym szczególnie się modlono, była przede wszystkim katedra wileńska i grób Kazimierza, a jednym z orędowników, których proszono o pomoc przed Bogiem, mógł być on sam. Zupełnie do tej sytuacji pasują: zarówno wcześniej (ale już w czasie najazdu moskiewskiego w 1513 r.) zanoszona przy tym grobie modlitwa Krzyckiego do Kazimierza, aby „wspomógł Ojczyznę i sławnego nie opuszczał brata" ${ }^{101}$, jak i prośba zanoszona do Swiętego, przekazana przez Ferreriego, ,aby wejrzał na poniżenie i smutek ten nasz i sprawil, by nie panowali nad nami nasi nieczyści wrogowie, schizmatycy" ${ }^{102}$.

Najmocniejszym jednak argumentem jest - jak już wspomniano sam fakt wypełnienia ślubów i rozpoczęcia natychmiast po zwycięstwie starań o kanonizację Kazimierza „,crebris epistolis et insignibus oratoribus" ${ }^{103}$. I tu wchodzimy na teren absolutnie pewny. Od 5 VI 1513 r. przebywał w Rzymie na Soborze Laterańskim Piątym abp Jan Easki ${ }^{104}$. Nie ma żadnych dowodów, aby podejmował tam jakiekolwiek starania o kanonizację Kazimierza aż do czasu, gdy 24 IX 1514 r. przybył do Wiecznego Miasta prepozyt wileński i sekretarz królewski Wawrzyniec Międzyleski, „który - jak pisał potem do króla Łaski — wśród innych spraw powierzonych sobie przez Wasz Królewski Majestat, wytrwale domaga się kanonizacji błogosławionego Kazimierza" ${ }^{105}$. Załącznikiem do królewskiego listu w tej sprawie mieli być jeńcy moskiewscy, w oczekiwaniu na których Łaski uprosił nawet przełożenie sesji soboru aż do 21 III 1515 r. ${ }^{106}$ Rzym świętował zwycięstwo pod Orszą w sposób niezwykle uroczysty, z modłami dziękczynnymi w samej bazylice św. Piotra ${ }^{107}$.

Wkrótce po przybyciu Międzyleskiego uzyskał on razem z prymasem i biskupem wileńskim Wojciechem Radziwiłłem audiencję u papieża (30 IX 1514 r.) i przedłożył mu prośbę królewską, wspierany przez wiceprotektora Polski kard. Piotra Accolti. Leon X, ku zdziwieniu Łaskiego,

rex ipse re vera christianus sit [...] Assiduis enim pro victoria supplicationibus, ea deinde parta, gratiarum actionibus templa omnia sonabant" (Epistola Pisonis

ad Joannem Cortium de conflictu Polonorum [...] cum Moscovitis, Basileae, apud

Jo. Frobenum, 1515; przedruk w AcTom 3 s. 205).

100 Zob. Chronicon Polonorum, Cracoviae 1521, s. 91.

s. 56)

101 "Affer opem Patriae, clarum ne desere fratrem" (Krzycki Carmina,

${ }_{102}$ Vita, k. A7v. Pełen tekst oryginalny w przypisie 152.

103 Vita, k. A7v.

104 Zob. W. D w or zaczek, Easki Jan, [w:] PSB 18 s. 231.

105 ,....] qui inter alia negotia sibi a Maiestate Vestra commissa, magno studio sollicitat canonisationem Beati Casimiri" (List z 16 stycznia 1515: AcTom $3 \mathrm{~s}$. 325). Poświadcza to także Paweł Planca w liście do króla z 15 I 1515 (tamże, s. 322).

$106 \mathrm{Zob}$. w/w list do Zygmunta Starego (AcTom 3 s. 325).

107 Tamże, s. 325. 
„ita visus est affici ac si canonisatio ipsa iam pridem fuisset sollicitata" ${ }^{108}$. W rezultacie już na tej audiencji otrzymał Międzyleski od papieża zlecenie przygotowania wstępnej dokumentacji procesowej, przewidzianej przepisami ${ }^{108}$, a $20 \times 1514 \mathrm{r}$. Łaski wystosował petycję do ojców odbywającego się wtedy w Lateranie V Soboru Powszechnego z prośbą o poparcie kanonizacji nie tylko Kazimierza, ale też i księżnej Kingi, Jana Kantego, Jacka Odrowąża oraz Szymona z Lipnicy ${ }^{110}$. Kronikarz Mario Sanudo świadczy, że została ona wręczona papieżowi 29 X $1514 \mathrm{r} .{ }^{111}$ Innych kndydatów na ołtarze dołączył, korzystając $\mathrm{z}$ okazji, sam abp Łaski, pierwszy „,insignis orator” wspomniany przez Ferreriego, niestrudzony promotor procesów kanonizacyjnych polskich sług Bożych, zwłaszcza księżnej Kingi i Jacka Odrowąża ${ }^{112}$.

Jednak faktycznie skoncentrowano się wówczas tylko na staraniach o kanonizację Kazimierza, ponieważ zajmujący się tymi sprawami adwokat konsystorialny Paweł Planca, tłumacząc królowi w liście z 15 I 1515 r., że „takie kanonizacje nie odbywają się bez wielkich oporów i liczni królowie oraz książęta od lat zabiegają o nie, a jednak nie mogą ich otrzymać", mówi tylko o Kazimierzu i obiecuje, że jego sprawa mimo tych trudności - będzie załatwiona. „Należy dalej kołatać i nie tracić nadziei" ${ }^{113}$. Zastosowano więc, jak widać, w całej rozciągłości obowiązującą procedurę kanoniczną niereagowania na pierwsze prośby i zachęcano do składania następnych. Odwlekły się one nieco, zwłaszcza po wyjeździe Międzyleskiego z Wiecznego Miasta (12 I 1515 r.) ${ }^{114}$. Król, któremu Swięcicki z tej racji przygania opieszałość, rozpoczął nową grę polityczną, w wyniku której dalsze jego starania o kanonizację brata nabiorą - oprócz niezaprzeczalnych wymiarów kultowych - także wyraźnego podtekstu politycznego, zwłaszcza po przypisaniu wstawiennictwu Kazimierza zwycięstw z 1518 i 1519 r.

108 Opis tych wydarzeń jest zawarty w liście prymasa Łaskiego do uczestników Soboru Laterańskiego $w$ sprawie kanonizacji Kazimierza $z \quad 20$ X 1514 . Kopia wpisana do akt procesu bł. Kingi w Archiwum Klasztoru SS. Klarysek w Krakowie, rkps $36 \mathrm{~B}$ s. $250-251$.

109 Tamże s. 252.

110 Tamże, s. 249-253.

111 Zob. W. P ocie cha, Królowa Bona (1494-1557). Czasy i ludzie odrodzenia, t. 1, Poznań 1949, s. 313; t. 2. Poznań 1949 s. 102.

112 Miał podobno przed wyjazdem na sobór do Rzymu nakazać klaryskom klasztoru starosądeckiego spisywanie cudów otrzymywanych za wstawiennictwem bł. Kingi; Zob. K. S zwarga, Starosqdecki ruch pqtniczy, Lublin KUL, s. 9 (maszynopis). Bł. Jacka próbował jeszcze potem włączyć w starania o kanonizację bł. Kazimierza (zob. niżej, przypis 164).

118 „Istae canonisationes non fiunt nisi cum magna difficultate, et multi sunt reges et principes, qui a multis iam annis institerunt pno aliis, et tamen non possunt habere finem. Quidquid sit [...] prosequendum est negotium et bene sperandum" (AcTom 3 s. 323).

${ }_{114}$ Zob. K. B a czkowski, Międzyleski Wawrzyniec, [w:] PSB 21 s. 46. 


\section{STARANIA O WSZCZẸCIE PROCESOW W LATACH 1515-1518}

Petycja o kanonizację Kazimierza, oficjalnie złożona w Rzymie w październiku 1514 r., została - przepisowo - pozostawiona bez odpowiedzi. Warunki do ponownego zgłoszenia prośby o rozpoczęcie procesu zaistniały, kiedy - ku zadowoleniu papieża Leona $\mathrm{X}$, pragnącego pogodzić i potem pchnąć wszystkich władców europejskich na Turcję Zygmunt Stary zdecydował się na zbliżenie do cesarza Maksymiliana I. W lipcu 1515 r. doszło do spotkania obydwu monarchów w Wiedniu i (razem z Władysławem Jagiellończykiem, królem Czech i Węgier) w Bratysławie, gdzie postanowiono zacieśnić więzi między Habsburgami i Jagiellonami przez nowe koligacje ${ }^{115}$. Odtąd sprawę kanonizacji Kazimierza, podniesionego do roli idealnego łącznika obydwu dynastii ${ }^{116}$, zaczęli popierać także Habsburgowie i główny zwolennik sojuszu z nimi, biskup przemyski i podkanclerzy koronny Piotr Tomicki, drugi „,insignis orator" wspomniany przez Ferreriego ${ }^{117}$.

Prawie natychmiast po powrocie króla i Tomickiego z Austrii do Krakowa ${ }^{118}$, zostały z kancelarii królewskiej wyekspediowane dwa listy monarsze: do papieża Leona $\mathrm{X}$ i do kardynała-protektora Polski Achillesa Grassiego, datowane 13 września $1515 \mathrm{r}$. W liście do papieża król przypomina mu już niegdyś złożoną prośbę „w sprawie brata swego Kazimierza” i oświadcza, że teraz ponownie jest „przynaglany przez częste dopominanie się ludów tej krainy", aby wyprosił u Jego Swiątobliwości to, „czego oczekuje wspólna wszystkich radość, połączona z pragnieniem, by przebadali świętość jego życia i pewność cudów ci, których cnocie i obyczajom wierzyć przystoi”. Prosi więc, aby papież „wreszcie (iam tandem) zlecił tę sprawę niektórym prałatom Królestwa, którzy by — według zwyczaju - tak przeegzaminowali dokumenty i świadectwa jego życia i cudów, aby - jeśli zasługiwał będzie na to - jak najszybciej został umieszczony w katalogu świętych" ${ }^{110}$. Kardynał Grassi miał

115 Zob. Z. Wojciechowski, jw., s. 52-53.

116 Por. mowę Vadianusa, wygłoszoną z okazji tego spotkania, cytowana niżej w przypisie 155 .

117 Zob. Ferreri, Vita k. A8r, oraz instrukcję papieską dla Ferreriego z 1 XI 1519 w: AcTom 5 s. 190.

118 Byli tam ponownie 25 VIII 1515 r. Zob. A. Gąs i o r owski, Itineraria dwu ostatnich Jagiellonów, „Studia historyczne” 16 (1973) z. 2 s. 261.

119 ,Spero Sanctitatem Vestram memoria tenere, quod in causa fratris mei Casimiri apud eam alias egerim, quem constat multis et magnis miraculis clarum et conspicuum esse, quandoquidem plurimos votorum suorum compotes factum esse manifestum est, qui ad eius sepulcrum nuncupatis votis ea persolvere non dubitarunt. Crebris igitur illius Provinciae populorum admonitionibus impellor, ut a Vestra Sanctitate petam ne diutius differre dignetur id, quod communis omnium leticia cum magno desiderio expectat, ut si probabile est eum vitae sanctitate et miraculorum certitudine clarum esse, debita $a b$ his inquisitio fiat, quorum virtuti 
tę prośbę zdecydowanie poprzeć ${ }^{120}$. W obydwóch listach czyta się zdecydowanie i pośpiech. Mimo to, także i tym razem petycja królewska pozostała bez odpowiedzi.

Po raz trzeci do sprawy kanonizacji brata powrócił król wczesną wiosną 1517 r. Przygotowywał właśnie w Wilnie decydującą, wielką wyprawę wojenną na Moskwę, „cum ingenti militum copia” ${ }^{121}$. Wtedy to, zagrożony dodatkowo sojuszem krzyżacko-moskiewskim ${ }^{122}$, wystosował 10 maja $1517 \mathrm{r}$. list do Leona $\mathrm{X} \mathrm{z}$ natarczywą prośbą, aby już tym razem nie zwlekał $\mathrm{z}$ oficjalnym rozpoczęciem procesu Kazimierza. Przypomina w nim, że cała ,gens patria” czci go ,jako błogosławionego z powodu nieskazitelności i świętości życia, wielkich cnót oraz zadziwiających cudów, które dla jego zasług się dzieją i przy jego grobie z Bożej łaskawości co dzień się mnożą". Zaznacza, że wnosi tę prośbę już po raz trzeci, „powodowany tylko częściowo efektem pokrewieństwa z Kazimierzem" znacznie ważniejszym bowiem motywem są żądania biskupa wileńskiego Wojciecha Radziwiłła, jego kapituły, własnych doradców, kleru i pobożnego ludu ${ }^{123}$.

$\mathrm{Z}$ listem tym oraz prawdopodobnie $\mathrm{z}$ innym, datowanym wcześniej (2 maja 1517 r.), a skierowanym do kolegium kardynałów (,prosił ich, aby zabiegali u papieża i sprawili, by Jego Swiątobliwość zaliczył w poczet świętych błogosławionego Kazimierza, brata tego króla, rozlicznymi

et vitae integritati merito fides habere debet. Oro itaque et obtestor, dignetur Vestra Sanctitas iam tandem aliquibus Praelatis Regni mei hanc provinciam demandare, qui de more documenta et testimonia eius vitae et miraculorum ita perquirant, ut si futurum est quod Cathalogo Illustrium [!] virorum ascribi meretur, celerius fiat" (Archiwum Główne Akt Dawnych, Sucha, rkps 22/32 s. 595-596). Kopia nie posiada daty ani miejsca napisania. Ich identyfikacja na podstawie datowania identycznego w treści listu króla do kard. Grassi „Cracoviae, tredecima die Semptembris" (zob. niżej, przypis 120). Data roczna obydwu może być tylko r. 1515, ponieważ między rokiem 1507 a 1518 Zygmunt Stary przebywał we wrześniu w Krakowie tylko w r. 1515; zob. A. G ą s i or ow ski, jw., s. 258-262.

120 Archiwum Główne Akt Dawnych, Sucha, rkps 22/32 s. 596-597, kopia. Król informuje, że pisze także do papieża, powtarza swą argumentacje ,in causa fratris nostri Casimiri, quem a triginta annorum spacio postquam e vita excessit multis miraculis clarum esse constat" i prosi Grassiego, by „dignetur apud suam Sanctitatem hoc negotium ita agere et promovere, ut celerius desiderio nostro satisfiat".

121 Rocznik swiętokrzyski, [w:] MPH 3 s. 92.

122 Zob. Z. Wojcie ch ow ski, jw., s. 60.

128 „Binis iam literis Sanctitati Vestrae supplicavi, ut Divum Casimirum, quem omnis gens patria, ob actam eius vitae integritatem et sanctimoniam, magnasque virtutes, ac demum ob stupenda miracula, quae meritis illius fiunt, et in dies Divina clementia apud sepulcrum eius multiplicantur, pro beato habet, credit et veneratur, seriei atque cathalogo Sanctorum adscribere dignetur. Nunc autem nonnullo equidem affectu necessitudinis in exaltationem eiusdem Divi Casimiri ductus (Theiner 2 s. 367). W oryginale znajdującym się w Archiwum Watykańskim data roczna jest nieczytelna $\mathrm{z}$ powodu uszkodzenia rękopisu. Wydawca $\mathrm{A}$. Theiner zrekonstruowal ją jako ,1516" ma podstawie podobieństwa tego listu z listami bpa Radziwiłła i franciszkanów (zob. niżej nry 127 i 128), nie zwróciwszy uwagi, że datowane są one według cyklu Zwiastowania (początek roku 25 marca) i że wobec tego w królewskim liście majowym należało wstawić datę „1517”. 
błyszczącego cudami" ${ }^{124}$ ), zostali wydelegowani do Rzymu przez władcę biskup Radziwiłł i sekretarz królewski Wawrzyniec Międzyleski ${ }^{125}$.

Listy królewskie zostały poprzedzone przez dwa inne, datowane jeszcze w lutym 1517 r. ${ }^{126}$ Dnia 17 t.m. pisał do Leona X biskup Wojciech Radziwiłł i jego kapituła, powiadamiając że przy grobie Królewicza dzieją się liczne cuda, tak że nie tylko Litwini, ,sed etiam vicinae et exterae nationes, uciekające się do Jego wstawiennictwa i doznające wsparcia, zgodnie głoszą go być błogosławionym". Dlatego proszą, aby papież zważywszy, że mówią prawdę i tylko prawdę - zaliczył go do grona świętych ${ }^{127}$.

$\mathrm{Z}$ podobną prośbą zwrócili się do Leona $\mathrm{X}$ dzień później franciszkanie wileńscy ${ }^{128}, \mathrm{z}$ ich wikariuszem prowincjalnym br. Pawłem na czele, powiadamiając również „ex debito professionis nostrae" o licznych cudach dziejących się przy grobie Królewicza, dzięki którym „ab omni clero et populo creditur esse beatus" ${ }^{120}$. Jednak motywacja ich prośby o kanonizację nie jest już tak dewocyjna, jak chociażby biskupia i później królewska. Zakodowane jest $\mathrm{w}$ niej napięcie towarzyszące przygotowaniom do wojny $z$ Moskwą i wiarą $w$ pomoc Kazimierzową $w$ potrzebie. Stwierdzają bowiem, że Litwa otoczona jest Tatrami, Scytami (!) i przede wszystkim ,perfidnymi, twardszymi od skały, schizmatyckimi Moskalami”. Aby od nich bronić Litwinów i „wzmocnić wiarę tego ludu, wybrał sobie Bóg księcia Kazimierza”. Należy przeto „dla wielkiego umocnienia tejże wiary na ziemi litewskiej", jak najszybciej go kanonizować ${ }^{180}$.

$124 \mathrm{Na}$ konsystorzu 4 XI 1517 r. kard. Farnese „legit literas Regis Poloniae scriptas ad Sacrum Collegium Reverendissimorum Dominorum Cardinalium, datas Vilnae die secunda Maii 1517, quibus eos rogabat, ut apud Sanctissimum Dominum Nostrum ita curarent et efficerent, ut Sua Sanctitas Beatum Casimirum, praefati regis fratrem, miraculis fulgentem, cathalogo sanctorum adscriberet" (AnRom s. 81).

${ }_{125}$ Zob. list Zygmunta I do Leona $\mathrm{X}$ z $10 \mathrm{~V} 1517$ (Theiner 2 s. 367).

${ }^{126}$ A nie 1516 r. - jak czyta F. Niewiero (jw., s. 80). Nie zwrócil on uwagi, że datacja obydwu listów brzmi ,anno ab Incarnatione Millesimo Quingentesimo Decimo Sexto". Ponieważ nowy rok, według obliczen ,ab Incarnatione", lub "ab Annuntiatione", rozpoczynał się dopiero w uroczystość Zwiastowania NMP" (25 marca), przeto' w przeliczeniu na cykl „Anno Domini” lub ,a Circumcisione", powszechnie u nas używany (początek roku 1 stycznia), datę noczną obydwu listów należało przełożyć na „1517”.

127 „Etiam vicinae et exterae nationes longe lateque ad eius suffragia confugientes "et sublevamen referentes beatum illum concordi voce proclamant" (Theiner 2 s. 374).

128 A nie bernardyni, jak chce $\mathrm{N}$ i e wi ero (jw., s. 80). Klasztor ,ad Beatam Virginem Vilnae in Arena", wymieniony w wyżej wspomnianym liście, należał bowiem do franciszkanów konwentualnych (zob. K. Kantak, Franciszkanie polscy, t. 1, Kraków 1937, s. 304). Wymieniony w nim wikariusz komisariatu litewskiego br. Paweł jest postacią nieznaną. Kantak zna tylko jedną wzmiankę o nim u Theinera (2 s. 400 ; zob. tamże, s. 317$)$.

${ }_{129}$ List jest wydany przez Theinera (2 s. $\left.373-374\right)$.

150 ,Deus [...] dignatus est Principem Kazimirum, pudicum secundogenitum Serenissimi Regis Poloniae, felicis memoriae, ad augendum ipsam fidem suam eligere, ac in eo spiritum timoris, consilii, iustitiae, veritatis et amoris ponens 
Jest godne uwagi, że w tym samym czasie, kiedy franciszkanie redagowali swój list, także kroniki bernardynów wileńskich odnotowały wzmiankę o poparciu również przez nich próśb o kanonizację Królewicza ${ }^{181}$, co pozwala przypuszczać, że podobne petycje wystosowały także inne klasztory wileńskie. Chodziło więc o jakąś dobrze tym razem zorganizowaną akcję, a datowanie zachowanych $w$ tej sprawie listów według cyklu Zwiastowania (początek roku 25 marca), u nas nie używanego, dowodzi, że inicjator akcji był jeden i to nietypowy. Czyżby franciszkanie?

Prawie czteromiesięczny odstęp między petycjami biskupa i franciszkanów a obydwoma królewskimi tłumaczy się prawdopodobnie faktem przybycia w marcu 1517 r. do Wilna posła cesarza Maksymiliana I Zygmunta Herbersteina. Proponował on pośrednictwo między Zygmuntem Starym i Wasylem Moskiewskim w celu zażegnania wojny i swatał niedawno owdowiałemu królowi krewniaczkę żony cesarza, Bonę Sforza ${ }^{182}$. Zygmunt I nie miał zamiaru zrezygnować z wyprawy na Moskwę w celu odzyskania Smoleńska, ale chętnie skorzystał z oferty pokojowego załatwienia sporów z krzyżakami, obiecując, że jeśli będzie miał zagwarantowany spokój od zakonu i zwrot terenów zajętych przez Wasyla, to wtedy gotów pójść razem z innymi na Turka, na czym tak bardzo zależało papieżowi Leonowi $\mathrm{X}^{183}$. Najoczywiściej $\mathrm{w}$ całą tę grę polityczną wkomponowano również królewską petycję o kanonizację Kazimierza, skoro posłem desygnowanym do jej zawiezienia do Rzymu został wytrawny znawca stosunków kurialnych i autor zaakceptowanego niegdyś na Soborze Laterańskim projektu wojny z Ottomanami Wawrzyniec Międzyleski, który już w r. 1514 sprawę kanonizacji Królewicza w wiecznym mieście załatwiał ${ }^{184}$. Biskup Radziwiłł był - mimo swej rangi - drugorzędną postacią tego poselstwa. Świadczy o tym milczenie źródeł (poza niżej wspomnianym listem cesarza do papieża), które wiele mówią o działalności w Rzymie Międzyleskiego, a nie wymieniają biskupa tak dalece, że nawet podejrzewano, iż w ogóle do Italii nie wyjechał. Jednak brewe Leona $\mathrm{X}$, mianujące go domownikiem papieskim, które przedstawił w $\mathrm{r}$. 1518 abpowi Easkiemu w Wilnie, aby się wybronić od wizytacji prymasowskiej, dowodzi, że w r. 1517 był w wiecznym mieście ${ }^{135}$.

Posłowie musieli wyjechać z Wilna wkrótce po datowaniu listu królewskiego do papieża w maju 1517 r., skoro już 4 sierpnia tegoż roku

[...] Eius cathalogo sanctorum adscriptio] erit magnum in hac terra Lithuaniae stabilimentum fidei" (tamże, s. 373-374).

${ }_{181}$ Zob. K. Ka ntak, Bernardyni polscy, t. 1, Lwów 1933, s. 183.

132 Zob. Z. Wo jcie chow ski, jw., s. 60.

138 Tamże, s. $60-61$.

134 W. Pociecha, Królowa Bona, t. 2 s. 102.

135 Zob. J. K or y tkow ski, Arcybiskupi gnieźnieńscy, t. 2, Poznań 1889, s. 643. 
byli w Kremonie, skąd polecał mu ich i sprawę kanonizacji Kazimierza sam cesarz Maksymilian I ${ }^{186}$. W drugiej połowie września dotarli do Rzymu, gdzie 29 tego miesiąca zostali przyjęci na audiencji przez papieża Leona $\mathrm{X}^{187}$. Na najbliższym konsystorzu Międzyleski wyłożył polskie propozycje działań przeciwko Turkom. Leon X był zdobyty. 4 XI 1517 r., na tym samym konsystorzu, powołano specjalną komisję kardynałów, która przy udziale posłów głównych mocarstw europejskich (zwłaszcza Międzyleskiego) miała opracować projekt krucjaty antytureckiej ${ }^{188}$. Pozostałą część obrad konsystorza poświęcono sprawie kanonizacji Kazimierza. Po odczytaniu listu Zygmunta I do kolegium kardynalskiego z $2 \mathrm{~V}$ 1517 r., „papież wzruszony prośbami, polecił powołać komisję in partibus do zbadania życia i obyczajów błogosławionego Kazimierza. Postanowiono wydelegować do tego, mocą brewiów, Przewielebnych Biskupów [...] aby zebrali informacje $\mathrm{w}$ tej sprawie i sporządzili proces ze świadectwami, a jego akta - jak to we zwyczaju - przesłali do Stolicy Apostolskiej" ${ }^{189}$. W zapisce akt konsystorialnych nie są wymienieni biskupi, których powołano do przeprowadzenia tego procesu. Wiemy jednak z późniejszego listu króla do papieża oraz z instrukcji papieskiej danej w r. 1519 Ferreriemu, że mandat ten otrzymali arcybiskup Jan Easki i biskup przemyski Piotr Tomicki ${ }^{140}$.

Sukces misji Międzyleskiego, dzięki jego zręczności dyplomatycznej, był więc kompletny. Wracał do Polski na początku r. 1518 nie tylko obsypany pochwałami i honorami papieskimi (hrabia laterański protonotariusz apostolski, legat papieski na uroczystości zaślubin Zygmunta I z Boną) ${ }^{141}$, ale także wiózł ze sobą brewia i wiadomość „o upragnionym wydelegowaniu komisji do spraw procesu kanonizacyjnego błogosławionego Kazimierza" ${ }^{142}$. W ten sposób, 32 lata po zgonie Królewicza, zakończy-

${ }^{180}$ List znajduje się w Archiwum Watykańskim: Lettere di Principi, rkps 2 k. 39. Został odkryty przez I vinskis a (Sv. Kazimieras s. 67). Por. Niewiero, jw., s. 81.

${ }_{187}$ M. S a nuto, Diari, t. 25 kol. 66. Cytuję za W. P o c i e c hą: Królowa Bona, t. 1 s. 313 (tu data 29 X); t. 2 s. 102 (data - prawdopodobniejsza - 29 IX).

188 W. Pociecha, Królowa Bona, t. 2 s. 102.

130 „Et propterea Sanctissimus Dominus Noster, cui etiam praefatus rex supplicabat, mota [!] precibus, commisit ut Commissio fieret in partibus super vita et moribus Beati Casimiri, et brevia committerentur Reverendis Patribus Dominis Episcopis [...], qui se informarent de hoc negotio, processusque conficerent una cum attestationibus, eosque, ut moris est, ad Sanctam Sedem mitterent" (AnRom s. 81).

140 Leon X pisze w instrukcji dla Ferreriego z 1 XI 1519, r., że ,alias Venerabilibus Fratribus Archiepiscopo Gnesnensi et Episcopo Premisliensi similem dederimus commissionem" (AcTom 5 s. 190). O Easkim ,una cum nonnullis Commissariis" mówi także król w liście do Leona X z 31 V"1518 r. (zob. niżej przypis 160).

${ }_{141}$ Zob. W. P ociech a, Królowa Bona, t. 2 s. 102.

142, ,...] commissionis processus super canonisatione beati Casimiri votivam expeditionem" (Leon X do Zygmunta Starego, 13 XII 1517; AcTom 4 s. 255256). 
ły się pomyślnie trzyletnie starania o oficjalne rozpoczęcie Jego procesu kanonizacyjnego.

Zanim przejdziemy do omówienia, jak został on przeprowadzony, wróćmy jeszcze na chwilę do motywów starań o jego zapoczątkowanie. Argument spontanicznego kultu ludowego, wytoczony we wszystkich petycjach oficjalnych, w których proszący odwołują się do cudów i znaków dziejących się przy grobie Kazimierza, jest zdecydowanie potwierdzany przez liczne źródła nieoficjalne (Agricola, Miechowita, Krzycki, Decjusz, Vadianus, Planca) i przez owe wota $\mathrm{z}$ wosku składane we wcale niemałej ilości i potem spieniężane na cel jego kanonizacji. Niezależnie od tego jak sobie historiografia laicka usiłuje interpretować fakty ${ }^{143} \mathrm{i}$ czy rzeczywiście także prosty lud - jak pisze król - domagał się kanonizacji Swiętego ${ }^{144}$, zaprzeczyć się nie da tego, co zgodnie stwierdzają król, biskup i franciszkanie wileńscy, że cały lud i kler zgodnie „uważali Kazimierza za błogosławionego i jako takiego go czcili" ${ }^{145}$. Wyjątkowo cennego świadectwa, potwierdzającego inne już wymienione, dostarcza współczesny, schizmatycki kronikarz ruski, który stwierdza, że „jehoże za swiatoho majut Lachy" ${ }^{146}$.

$\mathrm{Na}$ tym spontanicznym kulcie ludowym rozwijał się kult elitarny, oddawany Kazimierzowi przez ludzi upatrujących w Nim ideał chrześcijańskiego władcy. Biskup Ciołek bolał, wychwalając w r. 1501 przed papieżem cnoty i cuda Królewicza, że porwała go śmierć właśnie wtedy, kiedy najwięcej się po nim spodziewano ${ }^{147}$. Podobne nadzieje, jakie z Kazimierzem wiązali Polacy, potwierdził w r. 1513 Andrzej Krzycki, który godząc się z wolą Bożą, nie rezygnował jednak z usług Błogosławionego dla Ojczyzny i prosil go o przyjęcie z nieba patronatu nad Polską, królem Zymuntem, królową Barbarą, kanclerzem Krzysztofem Szydłowieckim i „całym dworem”. Kończył swoją modlitwę nad grobem Kazimierza wezwaniem: „Affer opem Patriae, clarum ne desere Fratrem" ${ }^{148}$. Zapotrzebowanie na opiekę Królewicza nad jego bratem i Ojczyzną daje się wyczuć już z tenoru pierwszych starań o kanonizację, podjętych $\mathrm{w}$ r. 1501 przez Aleksandra Jagiellończyka ${ }^{149}$, a po Krzyckim zgłosi je także inny sekretarz królewski Jost Ludwik Decjusz ${ }^{150}$.

Wolno chyba w tych świadectwach dopatrywać się początków patro-

143 Zob. M. Ko s m a n, s. 148, 152.

144 Zob. list króla do Leona $X$ z 10 V 1517 r. (Theiner 2 s. 367).

145 Tamże, s. 367, 373.

${ }_{146}$ Hustinskaja lietopiś. Przedruk J. Szujskiego w: SRP 2 s. 302. Kronika ta obejmuje lata 1480-1506. Wzmianka o Kazimierzu (nie zauważona przez historyków) może być więc najstarszym świadectwem jego kultu.

147 Zob. wyżej przypis 70.

$148 \mathrm{Krzycki}$ Carmina s. $54-56$.

149 Zob. wyżej przypis 84 i 86.

1 iะo De Jagiellonorum familia, s. 48. 
natu narodowego i rodzinnego ${ }^{151}$. Tym bardziej, że rychło - pod wpływem zagrożenia moskiewskiego z r. 1513 - zostanie on połączony z kultem ludowym i potwierdzony w ślubowaniach poprzedzajacych zwycięstwo pod Orszą. Cytowana przez Ferreriego modlitwa, zanoszona przy grobie Kazimierza przed wyruszeniem na bitwę, brzmiała: „Błogosławiony Kazimierzu, wierzymy, że jesteś szczególnym obrońca naszego rodu i tej Ojczyzny u Wszechmogącego Boga Patronem, wejrzyj na ten nasz smutek i poniżenie, aby nie panowali nad nami nasi nieczyści wrogowie, schizmatycy [...] Ulituj się nad błagającą Cię o wsparcie Ojczyzną, w której się urodziłeś i wychowałeś [...] Będziemy wytrwale zabiegać u papieża i uzyskamy, że umieści Cię między świętymi dla chwały religii chrześcijańskiej i wywyższenia Twojego Narodu" ${ }^{152}$. Kazimierz jest więc skutecznym obrońcą narodu (obojga narodów, nie tylko Litwy) i dlatego naród zobowiązuje się starać o Jego kanonizację. J. Fijałek nie odmawia tej modlitwie autentyczności ${ }^{153}$, a jego opinia znajduje potwierdzenie w liście prymasa Łaskiego do króla z Rzymu (16 I 1515 r.); zachęca go do nieustawania w zabiegach o kanonizację "tum honoris Maiestatis Vestrae, tum illustrationis Fratris Dominiorumque suorum causa" ${ }^{154}$.

Pogodzenie się Jagiellonów z Habsburgami w r. 1515 dało nowy bodziec do starań o kanonizację przez położenie nacisku na więzy krwi obydwu rodów w osobie Kazimierza. Dodało to w efekcie jego kultowi nowy, dynastyczny wymiar. W mowie do cesarza Maksymiliana i króla Zygmunta Starego, wygłoszonej w Wiedniu w r. 1515, Joachim Vadianus podkreślił bardzo mocno zarówno Kazimierzowe związki krwi z ojcem Jagiellończykiem, jak i matką Habsburżanką: „A cóż Kazimierz [...] w którego umiłowaniu chciał Najlepszy i Najwyższy Bóg pokazać śmiertelnikom jak bardzo krew Waszą ceni i uznaje?" ${ }^{155}$. Motyw dynastycznych powiązań był niewątpliwie powodem poparcia starań o wszczęcie procesu Królewicza przez cesarza Maksymiliana w sierpniu 1517 r. ${ }^{156}$ Ale z czasem przestanie on być ważny (chociaż właśnie ,,penes Divum

151 Sam Zygmunt I w liście z $10 \mathrm{~V} 1517 \mathrm{r}$. przyznaje, że prosi 10 kanonizację „,nonnullo equidem affectu necessitudinis [...] ductus" (Theiner 2 s. 367).

${ }_{152}$ „Dive Casimire, quem tutelam praecipuam generis nostri et huius Patriae Patronum apud Omnipotentem Deum esse confidimus, respice afflictionem et moerorem hunc nostrum ne dominentur nobis inimici nostri immundi, schismatici [...] Miserere Patriae opem tuam implorantis, in qua et natus et educatus es, [...] ut pro Christianae religionis splendore et tuae Nationis exaltatione te in sanctos referat Pontifex Maximus, omni studio laborabimus et iure efficiemus" (Vita, k. A7r).

${ }_{158}$ Zob. J. Fijałek, Opisy Wilna, s. 153.

154 AcTom 3 s. 325.

155 „Quid Cásimirus [...] in cuius amore Deus Optimus Maximus quam gratus sibi et acceptus vester sanguis esset mortalibus indicare voluit?" (AcTom 3 s. 401). 158 Zob. wyżej przypis 136. 
Cazymirum" zostanie pochowana w Wilnie Habsburżanka Elżbieta, pierwsza żona Zygmunta Augusta, zmarła w 1545 r.) ${ }^{157}$, a pozostanie narodowy, poszerzony w r. 1517 przez franciszkanów wileńskich i następnie w r. 1520 przez pierwszego nuncjusza kontrreformacji Ferreriego o aspekt kontrreformacyjny: „ne dominentur nobis immundi schismatici" ${ }^{158}$.

\section{PROCESY PRZEPROWADZONE PRZEZ ŁASKIEGO I FERRERIEGO}

Nie posiadamy tekstu brewiów, mocą których Leon $\mathrm{X}$ zlecił Łaskiemu i Tomickiemu przeprowadzenie procesu Kazimierza w Wilnie. Nie ulega jednak wątpliwości, że zawierały one zlecenie dochodzenia prawdy o świętości życia i autentyczności cudów zdziałanych przez Królewicza, a nie tylko stwierdzenia faktu istnienia Jego kultu, ponieważ zlecenie konsystorialne mówi wprost o ,sporządzeniu procesu wraz z zeznaniami" 159. Również król Zygmunt Stary, prosząc Leona X w dniu 31 V 1518 r. o dołączenie do tych dochodzeń sprawy Jacka Odrowąża, stwierdza, że papież „na liczne jego prośby o kanonizację błogosławionego Kazimierza... raczył w liście swoim polecić Janowi, arcybiskupowi gnieźnieńskiemu, legatowi i prymasowi Królestwa, by wraz z pewnymi komisarzami przeprowadził dochodzenie i przesłuchał świadków odnośnie świętości życia, wiary, postępowania i cudów, którymi z miłosierdzia Bożego jaśnieje" ${ }^{180}$.

Oznacza to, że zlecenie dane Międzyleskiemu przez Leona X w r. 1514, by stwierdził fakt istnienia kultu, zostało przezeń wypełnione, a pisma, które wtedy $\mathrm{w}$ tej sprawie przedłożył ${ }^{101}$, uznane za wystarczające, skoro Łaski miał teraz od razu zacząć od przesłuchania świadków odnośnie do świętości życia i prawdziwości cudów Kazimierza. Należy sądzić, że także listy biskupa wileńskiego i innych z lutego 1517 r., koncentrując się na informacjach o istnieniu kultu i cudów, wraz zapew-

157 Zob. MPH 3 s. 115.

158 Zob. wyżej przypis 152; por. także przyp. 23.

159 Zob. wyżej przypis 139.

160 „Posteaquam Sanctitas Vestra ad multiplices meas supplicationes pro canonisatione Divi Casimiri, germani mei, dignata est literis suis Dominum Joannem, Archiepiscopum Gnesnensem, Legatum et Primatem Regni mei, una cum nonnullis Commissariis deputare, inquisitionemque fieri, et testes recipi super vitae sanctimonia, religione, conversatione atque miraculis, quibus Dei Optimi Maximi misericordia claret mandare, idem Dominus Archiepiscopus Gnesnensis, dum mandatum Sanctitatis Vestrae exequeretur, mihi proposuit, ut sub uno processus tenore beati Jacincti Poloni [[...] apud Sanctitatem Vestram canonisationem impetrarem" (Archiwum Główne Akt Dawnych, Sucha, rkps 22/32 s. $597-598$, kopia).

101 Wspomina o nich Łaski w petycji z 20 X 1514 r.; zob. Archiwum Klarysek w Krakowie, rkps $36 \mathrm{~B}$ s. 252. 
nieniami, że są one prawdziwe ${ }^{162}$, upoważniały do zlecenia prymasowi od razu formalnego procesu; tym bardziej, że nakazano mu zacząc najpierw od „zasiągnięcia informacji o tej sprawie” i dopiero potem przystąpienia do przesłuchiwania świadków" ${ }^{163}$.

Prymas otrzymał brewia delegacyjne najpóźniej w maju 1518 r., a będąc zwolennikiem kanonizowania większej ilości przyszłych Patronów Ojczyzny, postanowił wykorzystać okazję i uprosił króla o list do Leona X (31 V 1518 r.) z prośbą, by ,sub uno processus tenore” pozwolił przeprowadzić dochodzenia kanonizacyjne także bł. Jacka Odrowąża ${ }^{164}$. Sprawa wymagała jednak czasu i nieco się potem skomplikowa$\mathfrak{l a}^{165}$, przeto Łaski, nie czekając na odpowiedź papieża, wyruszył już 27 lipca 1518 r. do Wilna, by - jak sam wyznaje w swoim testamencie przeprowadzić zlecone mu $\mathrm{w}$ brewe apostolskim „dochodzenie o świętości życia i o cudach dokonanych po śmierci błogosławionego Kazimierza" ${ }^{106}$.

Żadne współczesne źródła nie opisują szczegółów tego procesu. Musiał być jednak przeprowadzony szybko i mało starannie, skoro przybywszy do Wilna $w$ połowie sierpnia i załatwiając tam także inne ważne sprawy państwowe, zdołał go ukończyć przed 7 września, tj. przed dniem wyjazdu $z$ litewskiej stolicy ${ }^{187}$. Pisze $w$ swoim testamencie, że wszystkie swoje dochodzenia, ,tak jak je spisał w rejestrze, nakazał przesłać papieżowi, aby - jeśli król tego będzie sobie życzył - można było przystąpić do kanonizacji" ${ }^{168}$.

Wynikałoby więc $\mathrm{z}$ tego, że akta procesu przeprowadzonego w r. 1518 zostały przekazane do Rzymu. Nikt ich tam jednak do dzisiaj nie odnalazł; ale nie znaleziono ich także w Polsce. Z instrukcji danej później nuncjuszowi Ferreriemu wynika jednak, że były one przeglądane przez

162 Zob. Theiner 2 s. $373-374$.

${ }^{168}$ Zob. wyżej przypis 139.

${ }_{104}$ Zob. wyżej przypis 160. List ten - znajdujący się także w aktach procesu św. Jacka - wydał również Severinus L u bomolens is (De vita, s. 158-159). Echem tych wspólnych starań królewskich o kanonizację obydwu błogosławionych jest De Divo Hyacintho carmen Mikołaja Husowczyka, który przeciwstawiając Zygmunta Starego protestantom, ,qui stolide clamant sanctos non esse ferendos in templis, simulacra iubent efferre vetusta", chwali go: „Tu sanctis ornare novis delubra laboras [...] Quanta Hyacinthus agat pandis miracula Romae, Germanique tui Cazimiri gesta revolvis" (Nicolai H u s o vi i Carmina. Ed. J. Pelczar, Cracoviae 1894, s. 92). Husowezyk byl dworzaninem Erazma Cisołka i razem z nim przebywal w Rzymie w 1. 1518-1522.

165 Szczegółowo omawia te trudności Z. Obertyński (Dzieje kanonizacji, s. $92-101)$.

${ }_{166}, 27$ Julii descendi Lytuaniam triplici de causa: una, quia per breve apostolicum mandatum mihi erat facere inquisitionem de vitae sanctitate et post mortem de prodigiis beati Kazimiri” ( $\mathrm{H}$. Z Z issberg, Johannes Easki, S. 173; przedruk J. Kory tk ow ski, Arcybiskupi gnieznieńscy, t. 2 s. 643).

107 Korytk owski, jw., s. 643 .

168 ,ut in registris conscriptam, procuravi mitti Summo Pontifici, ut, si Maiestas Regia volet, procedatur ad canonisationem" (tamże). 
jakieś instancje kurialne i uznane za niewystarczające. Papież przyznaje bowiem, że zlecił niegdyś przeprowadzenie procesu Łaskiemu i Tomickiemu, ,ale prawdę należy dokładniej przebadać”, tak aby nuncjusz po powrocie ,mógł złożyć w tej sprawie pra w dzi w e świadectwo i rozwiać wszelkie wątpliwości" ${ }^{169}$. Także sam Ferreri w przemówieniu powitalnym do króla w Toruniu (21 II 1520 r.) mówi, że papież kazał mu, aby ,dobrze przejrzał zebrane do tej pory dokumenty” ${ }^{170}$. Wniosek z tego jeden, i to tłumaczący całoroczną zwłokę, która po tym nastąpiła: akta Easkiego złożono do lamusa.

Tymczasem trwała niezbyt udana kampania wojenna w celu odzyskania utraconych w wojnie z Moskwą ziem Wielkiego Księstwa. Wśród niepowodzeń, które Ferreri i Święcicki przypisują niewypełnieniu obietnicy ukończenia procesu kanonizacyjnego Kazimierza, miała się zdarzyć cudowna odsiecz oblężonego przez Moskali Połocka, gdy 27 sierpnia 1518 r. dwutysięcznej armii polskiej pod wodzą Jana Boratyńskiego ukazał się nieznany jeździec i wskazał bród na Dźwinie, po którym przeprawiwszy się, zaskoczyli wroga, zwyciężyli go i uwolnili oblężonych. „Uważano - pisze Wapowski - że tym, który wskazał bród był błogosławiony Kazimierz, brat króla Zygmunta" ${ }^{170 a}$.

Wieść o tym, podawana $\mathrm{z}$ ust do ust, przyczyniła się walnie do wzrostu pobożności ku Królewiczowi i podjęcia nowych starań o finalizację jego kanonizacji, zwłaszcza po następnym - przypisywanym również jego wstawiennictwu - zwycięstwie wojska polsko-litewskiego nad moskiewskim wczesną jesienią 1519 r., szczegółowo opisanym przez Ferreriego i potwierdzonym przez posła weneckiego w Budzie, Wawrzyńca Orio, który pisał do senatu Najjaśniejszej Rzeczypospolitej 24 X 1519 r., że przybył tam poseł króla polskiego „z wiadomością o wielkim zwycięstwie, jakie odniósł jego król nad Moskalami". W bitwie tej miało paść aż 25 tysięcy zabitych ${ }^{170 b}$.

Po tym ogromnie kosztownym zwycięstwie miał król - według Ferreriego - zdecydowanie zażądać od papieża kanonizacji brata. Faktycznie wiemy, że władca wystosował w tym czasie zaginiony dziś list do Leona X i swego posła w Rzymie Erazma Ciołka z propozycją wysłania do Moskwy nuncjusza, który by doprowadził do zawieszenia niewygodnej wojny z księciem Wasylem Moskiewskim, tak aby sam mógł spo-

160 „Nihilominus pro veritate diligentius indaganda tibi committimus [etc.], ut cum redieris, verum testimonium reddere, ac de omnibus certiores facere possis" (AcTom 5 s. 190).

s. 197).

${ }^{170}$, ,...] ut actitata hucusque monimenta mature perspiciamus" (AcTom 5

170a Kroniki, s. 156.

170b M. Sanuto, I diarii, t. 28 s. 60. 
kojnie rozprawić się $\mathrm{w}$ tym czasie $\mathrm{z}$ krzyżakami ${ }^{170 \mathrm{c}}$. Czy $\mathrm{w}$ listach tych prosił także o dokończenie sprawy kanonizacji Kazimierza? Prawdopodobnie tak, choć nie mamy na to niezbitych dowodów. W każdym razie, w październiku 1519 r. Leon X, który marzył o pogodzeniu Polski z Moskwą i rzuceniu ich na Turka ${ }^{171}$, zdecydował się wysłać do księcia Wasyla i króla Zygmunta biskupa Guardalfiery, Zachariasza Ferreri „pro pace componenda". Lecz w instrukcji, wystawionej 1 XI 1519 r., dodał mu także zlecenie, ,aby udał się do miejsca, gdzie spoczywa ciało błogosławionego Kazimierza i zebrał dokładne informacje o jego życiu i o cudach zdziałanych przez niego, zarówno po śmierci, jak i przedtem". Zebrane dowody miały być prawdziwe i dokładne, tak aby zaraz po powrocie nuncjusza można było „przystąpić do kanonizacji” ${ }^{172}$.

Ferreri dotarł do Polski w styczniu 1520 r. i w połowie lutego stanął przed Zygmuntem I w Toruniu. Tu w długiej mowie do króla, wygłoszonej 21 lutego, zachęcał go do zawarcia pokoju z krzyżakami, dodając - zgodnie $\mathrm{z}$ instrukcją - że Leon $\mathrm{X}$ pragnie kanonizować Kazimierza i dlatego „nakazał mi, abym dokładnie przejrzał zebrane do tej pory dowody jego świętości, obyczajności i czystości oraz jego chwalebnych cudów, i abym prowadził dalej w tej sprawie konieczne dochodzenia, które - zredagowane na piśmie - zawiozę do Rzymu, by poddać je osądowi papieża i kardynałów" ${ }^{173}$.

Do grobu Królewicza udał się Ferreri dopiero w lipcu 1520 r. Wjechał uroczyście do Wilna 2 września, witany u bram miasta $\mathrm{m}$. in. przez nowego (od 23 IX 1519 r.) biskupa wileńskiego, naturalnego syna Zygmunta Starego, Jana $\mathrm{z}$ Książąt Litewskich, oraz przez biskupa kijowskiego Jana Filipowicza i sufragana wileńskiego Jakuba z Miechowa ${ }^{174}$. Czy towarzyszyli mu oni później w wykonywaniu czynności procesowych, nie wiadomo. Nieszczęśliwie zredagowane streszczenie końcówki życiorysu Ferreriego przez bollandystów ${ }^{175}$ dało asumpt wszystkim do-

170c Zob. list do E. Ciołka: Archiwum Główne Akt Dawnych, rkps Sucha 22/32 s. 588.

171 Zob. list Leona $\mathrm{X}$ do Zygmunta I, 13 XII 1517 (AcTom 4 s. 225).

172 „Ut ad huiusmodi canonisationem matura deliberatione diligentique ipsius Kazimiri vitae et morum examinatione nec non miraculorum notitia et recensione prehabitis procedere valeamus [...] tibi committimus, ut te ad loca, ubi dicti Kazimiri corpus quiescere dicitur te conferas, et de eius vita ac miraculis per eum, tam post ipsius obitum, quam ante factis, te diligenter informes" (AcTom 5 is. 190).

173 „Nobis accuratissime mandavit, ut de eius sanctimonia, integritate et munditia gloriosisque miraculis actitata hucusque monimenta mature perspiciamus, omnesque ad id necessarias agamus investigationes, quas et scripto redactas ad ipsum Pontificem" (tamże, s. 197).

174 Vita, k. B1v.

175 ,Tres sunt episcopi ad latus Ill-mi Domini Zachariae Legati, Joannes Vilnensis, Joannes Chioviensis, Jacobus Caffensis Episcopi Latini. Examinata miracula et testes" (Acta Sanctorum Martii, t. 1 s. 349. 
tychczasowym hagiografom do twierdzenia, że stanowili oni łącznie z nuncjuszem trybunał procesowy ${ }^{170}$.

Zaraz po przybyciu do Wilna przystąpił Ferreri do wykonywania czynności związanych z procesem. Są one dokładnie takie, jakimi je opisali prawnicy kurialni XIV i XV w. Sam nuncjusz pisze, że wykonał wszystko, co należy „omni fideli opera et sedulitate exquisitissima [adhibita]". Zaczął od przesłuchania świadków, których wybrał „spośród ludzi najbardziej szlachetnych i godnych wiary, którzy byli obecni przy cudach i widzieli je, rękami dotykali i na samych sobie ich doświadczyli”. „Spośród niezliczonych cudów - jak pisze - które pod przysięgą zeznali, wybrałem jednak i kazałem spisać tylko te, które były ważne i wystarczające do udowodnienia świętości [Królewicza], a pominąłem niepotrzebne" ${ }^{177}$.

Wzmianka o znalezieniu pod głową Kazimierza tekstu hymnu „Omni die dic Mariae", dowodzi że nuncjusz otwierał także jego grób, co również należało do obowiązujących przepisów procesowych ${ }^{178}$. Zbierał także informacje o życiu i cnotach Kazimierza, by - zgodnie z wymogami kanonicznymi - napisać jego żywot. Ułożył go już 21 XI 1520 r. „,na podstawie zeznań wiarygodnych świadków" ${ }^{179}$ i dołączył do niego, w przewidywaniu rychłej kanonizacji Królewicza, także napisane przez siebie oficjum brewiarzowe i formularz mszy św. na cześć przyszłego świętego.

Ta pierwsza Vita Beati Casimiri ma całkiem specjalny charakter. Dużo w niej toposów, których - jak słusznie zauważył J. Fijałek nie należy traktować jak legendy, ale trzeba je czytać w relacji do mentalności, a przede wszystkim rozumienia prawdy historycznej przez ludzi tamtych czasów ${ }^{180}$. Poza tym (a nie zwrócono na to do tej pory uwagi), włączony w Żywot opis własnej podróży Ferreriego po Polsce i Litwie, z podkreślaniem egzotyki tych krajów, silnych mrozów, śniegu, wyraźnie wskazuje, że Vita była przeznaczona dla odbiorcy niepolskiego. Jej niezwykle szybkie jak na tamte czasy wydrukowanie u Hallera w Krakowie, brak daty druku i aureola wokól głowy Kazimerza na drzeworycie umieszczonym na pierwszej stronie dowodzą, że miała ona być przede wszystkim rozprowadzona $\mathrm{w}$ Rzymie $\mathrm{z}$ okazji kanonizacji, w której rychłe sfinalizowanie Ferreri musiał absolutnie wierzyć. Niemałą także rolę w przekazaniu jej drukarzowi odegrała prawdopodobnie chęć przy-

176 Twierdzenie to podtrzymuje także Ni ewi ero (jw., s. 82).

177 Vita, k. A8r.

${ }^{178}$ Sam pisze, że udawał się do Wilna, „ut sepulcrum divi Casimiri ibidem inviseremus" (tamże).

${ }_{179}$,Ex fide dignorum testium depositionibus” (podtytuß).

180 J. Fijałek, Opisy Wilna, s. 152. 
podobania się królowi, gdyż nuncjusz - jak się później okazało - był dosyć wrażliwy na godności i pieniądze ${ }^{191}$.

Wyjeżdżając z Wilna w marcu 1521 r. zabierał Ferreri ze sobą, oprócz gotowego do druku tekstu Żywotu i oficjum, także Processus mandati apostolici - a więc nakaz papieża wraz $\mathrm{z}$ instrukcją jak ma postępować, „teksty zawiadomień o wszczęciu procesu, wezwań do składania zeznań i ponagleń oraz traktaty, teksty kazań wygłoszonych $\mathrm{w}$ tej sprawie do kleru i ludu, opisy postów i modłów zanoszonych do Boga w intencji kanonizacji, informację o zachowywanym przez siebie porząd$\mathrm{ku}$ i ceremoniale $\mathrm{w}$ dochodzeniu cnót i cudów błogosławionego Kazimierza, zestawy pytań i odpowiedzi oraz dodatkowych oświadczeń świadków i współświadków, a także terminy wyznaczone na składanie zeznań przeciwnych oraz inquisitionis conclusio (podsumowanie procesu)". Wszystkie te materiały, według notatki opublikowanej przez nuncjusza w zakończeniu drukowanego Żywotu Kazimierza, zostały razem zebrane w osobnym tomie, który zamknięty i opieczętowany, miał być otwarty tylko przez papieża ${ }^{182}$.

Żegnał Ferreri Wilno po półrocznym pobycie hymnem, ułożonym na cześć Kazimierza na wzór Exultet:

Gaudeat inclyta et speciosa Italia [...]

Laetet ampla et spaciosa Sarmatia

Praeclara glorietur Polania

Excelsa gratuletur Lituania [...]

Exultet praecipue Vilna, insignis civitas,

Quae illa Eius ossa candissima,

Illas Eius dulces exuvias reliquiasque sanctissimas

In pignus servat futurae immortalitatis et gloriae ${ }^{\mathbf{1 8 8}}$.

Nie wiadomo, kiedy nuncjusz wyjechał z Polski; 7 IV 1521 r. był przy królu w Toruniu, gdzie wygłosił pochwałe pokoju i skąd prawdopodobnie razem $\mathrm{z}$ władcą wyruszył 25 kwietnia do Krakowa ${ }^{184}$; w stolicy Polski bawił na pewno przynajmniej do połowy lipca 1521 r., 27 czerwca, w uznaniu prac i zasług położonych przy ,dochodzeniu życia i cudów

181 Zob. list Zygmunta Starego do E. Ciołka z 1522 r.: Archiwum Główne Akt Dawnych, Sucha, rkps 22/32 s. 586-588.

182 „Processus mandati apostolici, intimationes, citationes, monitiones, tractatus, sermonesque habiti ad clerum et populum, ieiunia, supplicationes, ordoque et solemnitas servata $a b$ eodem $R$-mo Domino Legato in perquirendis gestis et miraculis Beati Casimiri, interrogatoria quoque ac responsa et dicta testium et contestium, eorum insuper promulgationes, terminique ad opponendum praefixi, et inquisitionis conclusio alio volumine longo schemate scripta sunt et eiusdem R. D. Legati sigillo clausa et obsignata, quousque per Beatissimum et Sanctissimum Dominum Nostrum Pontificem Maximum aperiantur" (Vita, k. C8r).

183 Vita, k. B2v-3r.

184 Zygmunt I przybył tam przed $6 \mathrm{~V} 1521$ (zob. Gąsiorowski, jw., s. 262-263). Mowe z datą jej wygloszenia w Toruniu wydrukował Ferreri jako załącznik do Vita B. Casimiri. 
świetlanej pamięci Kazimierza" oraz przy rokowaniach pokojowych $z$ krzyżakami, został obdarzony łaską używania połowy polskiego herbu królewskiego ${ }^{185}$. Przywilej, jakiego nie dostąpił nigdy żaden inny nuncjusz.

Chyba to wyróżnienie oraz niemałe datki pieniężne uczyniły Ferreriego tak rozentuzjazmowanym, że opowiadał później sekretarzowi królowej Bony Gian Andrea Valentino, ,iż prawie nie wie, kto bardziej zasługuje na kanonizację" - król czy Kazimierz ${ }^{186}$. Valentino relacjonując to, poświadczył przy okazji, że nuncjusz „wiezie ze sobą do Rzymu akta procesu błogosławionego Kazimierza [...] by go kanonizować" ${ }^{187}$. Tak więc misja Ferreriego skończyła się dla Kazimierza pełnym sukcesem i wydawało się, że już tym razem nic nie stanie na przeszkodzie zaliczenia Go w poczet świętych; tym bardziej że nuncjusz odjeżdżając z Krakowa do Rzymu dawał królowi ,niepróżne nadzieje” rychłej kanonizacji ${ }^{188}$.

\section{PROBLEM RZEKOMEJ KANONIZACJI W R. 1521 I KULT W XVI W.}

Jak potoczyły się sprawy dalej po wyjeździe Ferreriego z Krakowa, pozostaje tylko w sferze domysłów i nie potwierdzonych informacji późniejszych. Przekaz Święcickiego o dokonaniu uroczystej kanonizacji w Rzymie przez Leona X i o zaginięciu bulli kanonizacyjnej wręczonej Ciołkowi ${ }^{189}$, dziś już nie wytrzymuje krytyki historycznej. Swiadczą przeciw niemu argumenty zebrane przez Niewierę ${ }^{190}$ i przede wszystkim odnaleziony przez Fijałka fragment instrukcji Zygmunta Starego dla swego posła do Rzymu Jana Wilamowskiego z r. 1539 z prośbą o ,zaliczenie nareszcie błogosławionego Kazimierza do katalogu świętych" ${ }^{101}$

Pomimo pewności, że kanonizacji Kazimierza za życia papieża Leona X nie było, nie można jednak wykluczyć, że nie uczyniono ku niej po przybyciu do Rzymu Ferreriego następnego kroku. Nie muszą mylić się bollandyści (chociaż prawdopodobnie sami sobie to bez oparcia

185 Odnośny dyplom Zygmunta I w Archiwum Głównym Akt Dawnych, Metryka Koronna, rkps 37 k. 203v.

186 „Ha detto che non sa quasi chi piú meritasse la canonisatione, o egli, o el beato Casimiro" (Valentino do księcia Ferrary Alfonsa d'Este, Kraków 15 VII 1521). Cytuję za W. P ocie chą (Królowa Bona, t. 2 s. 519).

187 „El quale porta el processo a Roma del beato Casimiro, fratello carnale di questo re per canonizzarlo" (tamże, s. 519).

188 „Non vanam spem fecit futurae canonisationis" (zob. dyplom Zygmunta I dla Ferreriego, jak w przypisie 185).

189 Oratio Svencicii, [w:] Theatrum s. 64.

190 Zob. F. Ni e wi ero, jw., s. 83-86.

191 „Commendabit praeterea de fratre nostro, divo Casimiro, ut iam tandem in cathalogum sanctorum per eius Sanctitatem adscribatur" (J. Fijałek, Opisy Wilna, s. 149). 
o źródła dopowiedzieli) twierdząc, że jeszcze przed śmiercią Leona X (1 XII 1521 r.) akta przywiezione przez nuncjusza zostały przez papieża „W czasie posiedzenia Najdostojniejszych Purpuratów, dokładnie przejrzane, poddane egzaminowi i zaaprobowane" ${ }^{102}$, czyli że dokonano ostatniego aktu, poprzedzającego uroczyste ogłoszenie kanonizacji.

Możliwość zaistnienia takiego aktu jest realna $\mathrm{z}$ dwu powodów: (1) rzeczywistej obecności $\mathrm{w}$ Rzymie obrotnego, lubianego przez Leona $\mathrm{X}$ i zaangażowanego od dawna $w$ sprawę Kazimierza, posła królewskiego Erazma Ciołka, który - jak wynika z listu Zygmunta Starego do niego z 1522 r. - był inicjatorem wysłania Ferreriego do Polski w r. $1519^{193}$ i na pewno po powrocie nuncjusza do Rzymu sprawę dalej popierał; (2) o niej to bowiem myślał król, nie aprobujący innych akcji kościelno-politycznych posła w kurii, kiedy na wieść o jego śmierci wyrażał żal, że $\mathrm{z}$ jej powodu wiele spraw w Rzymie się powikłało ${ }^{194}$. Drugi powód to skojarzenie sprawy kanonizacji Kazimierza ze sprawą kanonizacji Jacka Odrowąża. Już w r. 1514 i 1518 usiłowano połączyć je ze sobą w jeden proces, w r. 1521 - po pewnych komplikacjach - Erazm Ciołek uzyskał na konsystorzu 28 sierpnia wyznaczenie sędziów delegowanych do przeprowadzenia procesu dominikanina ${ }^{195}$. Nie jest wcale wykluczone, że Ferreri mógł już wtedy znajdować się $w$ wiecznym mieście i że po przejrzeniu na tym samym konsystorzu przywiezionych przez niego materiałów wyznaczono taką samą komisję trzech kardynałów do sfinalizowania kanonizacji Kazimierza, jaka potem - 17 XII 1526 - została wyznaczona do przeegzaminowania akt procesu Jacka ${ }^{198}$.

W każdym razie Leon $\mathrm{X}$ nie zdążył na pewno sprawy kanonizacji Królewicza ukończyć. Nie wydaje się, by chciał się nią zająć jego następca, wrogi królowi polskiemu papież Hadrian VI ${ }^{197}$. Tymczasem zmarł w Rzymie w r. 1524 biskup Ferreri ${ }^{108}$. Za Klemensa VII (1523-1534) przedłożono w r. 1526 - jak już wspomniano - do ostatecznego sfina-

192 Acta Sanctorum Martii, t. 1 s. 350.

193 Kopia w Archiwum Gł6wnym Akt Dawnych, Sucha, rkps 22/32 s. 588.

$194 \mathrm{H}$. Folwarski, jw., S. 195.

195 Zob. Z. O bertyński, jw., s. 95.

196 Tamże, s. 102-103. Zapiska akt konsystorialnych, mówiąca, że na tym konsystorzu ,fuit productus processus ex Polonia factus super canonisatione fienda B...", nie ma wpisanego imienia tego polskiego kandydata na oltarze. Jej wydawca J. Korzeniowski (AnRom s. 88) a za nim F. Ni e wi er o (jw., s. 84-85) sądzą, że rozpatrywano wtedy sprawę bł. Kazimierza. Zapiskę tę miał w ręku już przed r. 1594 Seweryn z Lubomla $i$ on także mial wątpliwości odnośnie do owej, jak ją nazywa, „lacuny”, ale z dużą dozą prawdopodobieństwa wykazał, że mogła się ona odnosić tylko do św. Jacka (zob. S. Lubomlus, De vita, miraculis et canonisatione S. Hyacinthi, Romae 1594, s. 232).

197 Panował tylko od 9 I 1522 do 14 IX 1523. Negri, jego nuncjusz w Polsce, nic o kanonizacji Kazimierza nie wspomina; nie nalega też na nią król Zygmunt; zob. AcTom t. $6-7$ passim.

198 Zob. A. M a n cone, Ferreri Zaccaria, [w:] Enciclopedia Cattolica, t. 5. Città del Vaticano 1950, kol. 1199. 
lizowania akta procesu bł. Jacka. Nie jest wykluczone, że także i wtedy strona polska próbowała pchnąć sprawę Kazimierza. Wkrótce potem $(6$ V 1527 r.) miało miejsce straszliwe sacco di Roma - splądrowanie i spalenie wiecznego miasta przez wojska cesarza Karola $\mathrm{V}^{109}$. W czasie tej tragedii zaginęły na pewno akta procesu bł. Jacka ${ }^{200}$. Ten sam los - jak suponuje F. Niewiero - mógł spotkać także akta procesu bł. Kazimierza ${ }^{201}$, o ile one w ogóle kiedykolwiek znajdowały się w Watykanie. Są bowiem również hipotezy diametralnie odwrotne, chociaż mało prawdopodobne, że akta procesu przeprowadzonego przez Ferreriego nigdy do Rzymu nie dotarły. Hipotezę tę postawił już w 1593 r. nuncjusz Germanik Malaspina, protestując przeciwko włączeniu Kazimierza jako świętego do Martyrologium Rzymskiego (1583) i uświadamiając kard. Aldobrandiniego, że Królewicz nie był kanonizowany, „lecz przeprowadzono tylko jego proces, którego akta dziś znajdują się w Wilnie" ${ }^{202}$. Wiadomość ta, podana $\mathrm{z}$ Warszawy, jest jednak albo całkowicie błędna, albo odnosi się do akt procesu przeprowadzonego w r. 1518 przez Easkiego, jeśli takowe (co jest bardzo prawdopodobne) były przywiezione do Polski przez Ferreriego $\mathrm{i}$ wykorzystane $\mathrm{w}$ Wilnie, a następnie (co jest mało prawdopodobne) przekazane biskupowi wileńskiemu, jako już nie potrzebne. Natomiast co do akt Ferreriego, to Valentino świadczy, że nuncjusz miał je na pewno ze sobą przynajmniej w Krakowie, w drodze do Rzymu. I tam chyba jednak dotarły.

Zwłoka, jaka nastąpiła po sacco di Roma w doprowadzeniu do kanonizacji bł. Jacka, spowodowała, że dominikanie polscy zwrócili się do biskupów zebranych na synodzie prowincjonalnym w Piotrkowie i uprosili ich o list postulacyjny do papieża Pawła III (1534-1549) z 20 V 1539 r. ${ }^{203}$ Wiózł go do Rzymu delegat synodu, kantor krakowski i sekretarz królewski Jan Wilamowski. Wszystko wskazuje na to, że w torbie podróżnej miał podobne pismo w sprawie bł. Kazimierza, ponieważ znajdująca się tam także instrukcja królewska nakazywała mu równie mocno prosić o kanonizację Królewicza ${ }^{204}$.

Jaka była reakcja Stolicy Apostolskiej na te supliki, nie wiadomo.

199 Zob. P. Pecchiai, Roma nel Cinquecento, Bologna 1948, s. 29-42.

200 Zob. Obertyński, jw., s. 112.

201 Zob. F. Ni e wi e ro, jw., s. 86.

202 "[...] ma si fece solo il processo, il quale si ritrova ancora in Vilna". List z 6 III "1593, odnaleziony przez P. Rabikauskasa w Archiwum Watykańskim (Fondo Borghese, III 66 C-D k. 65v); zob. Bibliotheca Sanctorum, t. 3 kol. 900.

${ }_{203}$ Zob. O bertyński, jw., s. 111.

204 Zob. wyżej przypis 191. Suplika w sprawie bł. Jacka nie była częścią postanowień synodalnych; została napisana już po zamknięciu obrad (zob. J. S a wicki, Analecta $z$ rękopisów bibliotek warszawskich, „Prawo Kanoniczne” 3, 1960, nr 1-2 s. 337). O wydelegowaniu Wilamowskiego przez synod - tamże, s. 355 . 
Potem zażądano dla Jacka rozpoczęcia procesów od początku, ponieważ jego akta zginęły. O Kazimierzu zapomniano. F. Niewiero sugeruje, że przyczyną tego była reformacja, która także znacznie osłabiła kult Królewicza ${ }^{205}$. Czy jednak? Lub czy tylko iona? Kult Kazimierza przy jego grobie i w całej Rzeczpospolitej Obojga Narodów wcale nie zmalał. Zapiski w aktach kapituły wileńskiej świadczą, ize przez jego kaplicę (przy której byli instalowani już od początku XVI w. dwaj mansjonarze) przewijały się przez cały ten wiek liczne rzesze możnych i ludu, którzy składali na jego cześć mnogie wota, ofiary pieniężne i wosk z przeznaczeniem na wydatki kanonizacyjne. Co więcej, ich ilość i wartość systematycznie wzrastała, przynajmniej do r. 1526. Pierwszego lutego 1521 r., w czasie obecności Ferreriego w Wilnie, wyjęto ze ,skarbca św. Kazimierza", stojącego na środku jego kaplicy (prawdopodobnie od r. $1502)^{206}$ i zamykanego na 3 klucze, 22 kopy groszy i 4 dukaty w złocie. W sierpniu 1522 r., w czasie któregoś z następnych otwarć, znaleziono w nim 20 dukatów węgierskicch i ponad 4 kopy groszy ${ }^{207}$. Obok ofiar pieniężnych składano w niemałej ilości wota z wosku. W lutym $1521 \mathrm{r}$. zebrano go aż 9 kamieni, tj. ok. $115 \mathrm{~kg}$, a w listopadzie 1523 r. ilość jego była dwukrotnie większa ${ }^{208}$. Sprzedawano go następnie, a pieniądze uzyskane ze sprzedaży przeznaczano na wydatki związane $z$ kanonizacją Królewicza ${ }^{209}$. Także kradzieże wot, jakie się w tej kaplicy zdarzały (np. w r. 1522 naszyjnika dzierzganego z pereł) ${ }^{210}$, dowodzą że kult błogosławionego był znaczny, zarówno wśród wielmożów, jak i wśród ludu. Musiał on rosnąc w następnych latach, skoro w październiku $1525 \mathrm{r}$. biskup Jan uznał za konieczne ustanowić kolegium aż trzech księży do pilnowania Kazimierzowego skarbca i kazał spisać rejestr metalowych wot, srebrnych insygniów oraz ofiar w srebrnych i złotych monetach, „których - oprócz wosku - tam się widziało wiele" ${ }^{211}$. Wiele też było ich i później. Za panowania Augusta (1548-1572) kustosz kapituły ks. Ji. Makowiecki wypłacił do skarbca królewskiego z tej skarbony 500 groszy. Nie musiała to być mała suma, skoro jej zwrotu domagała się kapituła jeszcze w r. 1583 od spadkobierców niewiernego kanonika ${ }^{212}$. Tak więc, skoro były ofiary, musiał być także kult.

205 Zob. F. Niewierio, jw., s. 86.

208 Od czasu wprowadzenia odpustów mocą bulli Aleksandra VI z 15 V 1501 r.; zob. wyżej przypis 82.

207 Zob. akta kapituły wydane przez J. Kruczewskiego: Kościót zamko$w y$, t. 3 s. $10,12$.

208 Tamże, s. 10, 17.

$209 \mathrm{Za}$ owe $115 \mathrm{~kg}$ wzięto w r. $152115 \mathrm{kop}$ i 20 groszy (tamże, s. 10). W listopadzie 1523 r. kapituła żądała od kanonika Wieleżyńskiego zwrotu 27 kóp groszy uzyskanych ze sprzedaży wosku składanego w kaplicy na kanonizację (tamże, s. 17). 210 Tamże, s. 13.

211 Tamże, s. 23.

212 Zob. F. Niewierı, jw., s. 86. 
Oprócz wosku, insygniów i darów pieniężnych o kulcie relikwii Kazimierza w drugiej połowie XVI w. świadczą także „votivae tabellae anathemataque”, które Swięcicki później widział „magno munere ad eius monumentum suspensa" ${ }^{213}$.

Także poza Wilnem kult Królewicza bynajmniej nie przygasł. Pod koniec lat dwudziestych XVI w. zaczęto przypisywać Kazimierzowi jak już wspomniano - udaną odsiecz Połocka w r. $1518^{214}$. Do rozpropagowania tego „cudu” przyczynił się walnie sekretarz królewski Bernard Wapowski, który - niezależnie od prawdziwości podanej przez siebie pogłoski o ukazaniu się Błogosławionego pod Połockiem - wiarygodnie stwierdza na innym miejscu swej Kroniki, ostatecznie zredagowanej przed śmiercią w r. 1535, że Kazimierz ,zadziwiającymi dziś, co jest zupełnie pewne, jaśnieje w sposób oczywisty cudami świętości" ${ }^{215}$ i dlatego „dziś, co jest również pewne, Litwini szczycą się szczególną tegoż Blogosławionego opieką" ${ }^{216}$.

Podobnie do żywego wciąż kultu swego świątobliwego brata i wcześniej zebranych dowodów Jego świętości nawiązywał w następnej prośbie o Jego kanonizację w r. 1539 król Zygmunt Stary ${ }^{217}$. Nie było to tylko tendencyjne wyolbrzymianie faktów przez władcę zainteresowanego wyniesieniem na ołtarze swego brata. Klemens Janicki w r. 1542 w przedmowie do Pieśni weseinej dla Najjaśniejszego Króla Polskiego Zygmunta Augusta, adresowanej dn Zygmunta Starego, każe mu szczególnie cieszyć się, że miał takiego brata, ,którego Wilno czci jako błogosławionego. U jego prochów dzięki składają Bogu Zbawicielowi liczne tłumy tych, których modły się spełniły, jak się to dzieje na Zachodzie u świętych progów Kompostelli i jak u grobów twoich, sławny Tybrze" ${ }^{218}$.

I w końcu Marcin Kromer, podsumowujący ok. r. 1545 niejako na całą resztę XVI w. kontynuację kultu bł. Kazimierza i sprowadzający go za Ferrerim do charakterystycznego dla całej potomności aż do dni naszych uwielbienia niezwykłej czystości Królewicza. Pisze bowiem w 29 księdze swej Historii: „O Kazimierzu, że był święty, nie tylko jednostajna sława, ale też pewne i ważne świadectwa twierdzą [...] Młodzie-

213 Oratio Svencicii, [w:] Theatrum, s. 62.

214 J. Fijalek (Opisy Wilna, s. 152) sądzi, że to sam Wapowski skojarzył z Kazimierzem inny współczesny opis tej odsieczy, zamieszczony $\mathrm{w}$ Roczniku świętokrzyskim (MPH 3 s. 95 n.)

${ }_{215}$ "Stupendis hodie, quod satis constat, aperte sanctitatis claret miraculis" (B. Wa pow ski, Kroniki, s. 2).

218 „Hodie, quod satis constat, Lithuani eius Divi singulari gloriantur patrocinio, cum stupendis clareat miraculis (tamże, s. 156).

${ }^{217},[. .$.$] quandoquidem clarissimis miraculorum documentis et multis testimoniis$ et mortuorum [resurrectione] vita eius innocens et sancta est investigata" ( $\mathrm{z}$ instrukcji dla posła Wilamowskiego - J. Fijałek, Opisy Wilna s. 149).

${ }^{218} \mathrm{~K}$. Janicki, Carmina. Dzieła wszystkie. Wyd. J. Krókowski. Tłumaczenie polskie E. Jędrkiewicz, Wrocław 1966, s. 195 (na s. 194 oryginał łaciński). 
niec był $\mathrm{w}$ rozumieniu świątobliwości zawzięty. Sławią tedy tak czystym i wstrzemięźliwym być żywot jego, że gdy lekarze radzili [... on] umrzeć raczej niż kiedy zakon pobożności chrześcijańskiej przestąpić wolał, daleko inaczej rozumiejąc aniż wiele ludzi w zepsowanym teraźniejszym wieku żyjących, którzy ani za grzech, ani za sromotę poczytują sobie w błocku plugawego wszeteczeństwa polegać" ${ }^{219}$.

\section{KANONIZACJA ROWNOZNACZNA W R. 1601}

Po objęciu rządów w Polsce przez Zygmunta III Wazę (1587) sprawa zakończenia procesu kanonizacyjnego bł. Kazimierza staje się ponownie bardzo aktualna i to $\mathrm{z}$ dwu powodów: dynastycznego i konfesyjnego. Nowy władca - pouczony przez jezuitów, którzy stają się teraz głównymi promotorami kultu i wyniesienia Królewicza na ołtarze pragnie umocnić swe rządy i zapewnić rodowi sukcesję w Polsce przez podkreślenie ciągłości krwi jagiellońskiej (przez matkę). Wszystko wskazuje na to, że popierając kanonizację Kazimierza, chciał te związki szczególnie podkreślić. Piotr Skarga, dobrze zorientowany w poglądach dworu, napisze później, że papież Klemens VIII „wsławił” kanonizację dokonaną w r. 1521 r. przez Leona X, ,zachęcony nabożeństwem bogobojnego króla, Pana Naszego Miłościwego Zygmunta Trzeciego, który się w nim jako w swej krwi trzeciego pokolenia barzo zakochał $\mathrm{i}$ na syna swojego wtórego imię włożył; za prośbą też Prześwieconej Małżonki swej Konstancji [Habsburżanki], która się też krwie tegoż świętego dotyka" ${ }^{220}$. Miał to być więc powrót do patronatu Kazimierza nad panującą dynastią $\mathrm{w}$ jej nowej szacie, ale $\mathrm{w}$ starych sprawach politycznych zagrożeń państwa. „I teraz w te wojny z Moskwą - kończy Skarga - będzie ku pewnej pomocy, jako to już pierwej czynił, aby katolickiego Królestwa nie psowali" ${ }^{221}$.

Drugi motyw, jeszcze wyraźniej dający o sobie znać w staraniach podjętych w końcu XVI w., wyrastał z przełomu konfesyjnego, dokonującego się $\mathrm{w}$ Polsce $\mathrm{i}$ na Litwie $\mathrm{w}$ ostatniej ćwierci tego wieku. Nie tylko stopniowe powracanie katolicyzmu na utracone pozycje, ale także i nowy duch pobożności trydenckiej zwiększyły zapotrzebowanie na rodzimych herosów wiary, którzy w iście barokowej oprawie mieli świadczyć nie tylko o jej egzaltacji, ale także i zakorzenieniu w dziejach tego narodu. Zachęcał Polaków Skarga włączywszy Kazimierza (obok bł. Jana Kantego i Stanisława Kostki) do Przydatku swoich Żywotów Świę-

210 M. Kromer, Kronika polska, t. 3, Sanok 1868, s. 1298-1299.

${ }_{220}$ P. Skarga, Zywoty świętych, (wyd. 7) Kraków 1610, s. 1161-1162.

221 Tamże, s. 1162. 
tych: „I też modlitwie Jego za nas dufajmy, iż jest krew nasza, domownik nasz, Królestwa tego Syn i miłośnik ludu swego" ${ }^{222}$.

Kiedy jednak i kto podjął bezpośrednie działania w celu sfinalizowania kanonizacji bł. Kazimierza - nie wiadomo. Niewiero twierdzi, że inicjatywa wyszła od samego papieża Klemensa VIII (1592-1605), który w latach 1588 - 1589 był legatem papieskim w Polsce ${ }^{223}$. To on miał zachęcić biskupa wileńskiego Benedykta Woynę, ,aby podjął starania o definitywne dopełnienie formalności kanonizacyjnych" ${ }^{224}$. Rzecz jednak $\mathrm{w}$ tym, że Niewiero wyczytuje to $\mathrm{z}$ epitafium tegoż biskupa (zmarłego w r. 1615), które brzmi: „Divi Casimiri, tutelaris Lithuaniae, iam paene sepultos honores an nuente Pontifice Maximo Clemente denuo instauravit” ${ }^{225}$. Czyli że papież nie ,zachęcał”, lecz tylko „wyrazil zgodę” na „odnowienie prawie pogrzebanych honorów” Królewicza.

Ich „odgrzebywanie” zaczęło się już przynajmniej przed r. 1583, w! którym imię Kazimierza znalazło się w Martyrologium Romanum, opublikowanym po raz pierwszy w tym właśnie roku ${ }^{226}$. Nie wiadomo, kto zabiegał, by je tam umieścić. Może jezuici, którzy z Piotrem Skargą na czele byli $\mathrm{w}$ bardzo bliskich kontaktach z głównym jego redaktorem Cezarym Baronio ${ }^{227}$. Problem ten nie mógł być obcy Skardze także $\mathrm{z}$ innego powodu. Właśnie w Wilnie, niemal przy grobie Królewicza, pisał swoje Żywoty świętych. Wprawdzie nie umieścił go, zachowując rygorystycznie porządek zatwierdzonego kalendarza liturgicznego, ani w ich pierwszym wydaniu z 1579 r., ani w sześciu następnych ${ }^{228}$, ale że był jego wielkim czcicielem świadczy to, co napisał o nim w cytowanym już wydaniu Żywotów z 1610 r. oraz jeden z najstarszych obrazów Świętego, ofiarowany przez niego potem fundatorce klasztoru karmelitów bosych w Czernej Agnieszce Firlejowej ${ }^{229}$.

„O potrzebie kanonizowania świętych polskich: Jacka, Kazimierza, Kunegundy" wspomniał także w czasie posiedzenia kongregacji kardynałów w Rzymie (30 VI 1586 r.) kardynał Andrzej Batory, namówiony do tego przez swego sekretarza Stanisława Reszkę ${ }^{230}$. No i wreszcie sama

222 Tamże, s. 1162.

223 A nie nuncjuszem w latach 1585-1590, jak błędnie twierdzi $\mathrm{N}$ i e wie r o (jw., s. 83).

${ }^{224}$ F. Ni e wi e r o, jw., s. 86.

225 Tamże, s. $83,86$.

226 Zob. Bibliotheca Sanctorum, t. 3 kol. 899.

227 Zob. P. Skarga, Listy z lat 1566-1610. Wyd. J. Sygański, Kraków 1912, passim.

228 Uczynił to dopiero w wydaniu siódmym z r. 1610. Zwróćmy jednak uwage, że także i święci jezuiccy: Ignacy Loyola i Franciszek Ksawery znaleźli się tam tylko w Przydatku.

229 Zoib. B. J. W a n a t, Zakon karmelitów w Polsce, Kraków 1979, s. 337.

${ }^{230}$,In ea congregatione fecit noster, me instigante, mentionem de Sanctis Polonis canonisandis: S. Hyacintho, Casimiro, Kunegunde" (Stanislai Rescii Diarium 1583-1589. Ed. J. Czubek, [w:] Archiwum do dziejów literatury $i$ oświaty $w$ Polsce, t. $15 \mathrm{cz} .1$, Kraków 1915, s. 134). 
kanonizacja św. Jacka, towarzysza Kazimerzowskiego w procesach, uroczyście ogłoszona 17 IV 1594 r. ${ }^{231}$, musiała także zdopingować do zajęcia się również jego sprawą.

Wszystko wskazuje na to, że jednak projekt oficjalnego wystąpienia do Stolicy Apostolskiej z wnioskiem o kanonizację Królewicza narodził się za sprawą króla Zygmunta III w czasie trwania sejmu warszawskiego (9 II-21 III 1600). W sejmie tym brali udział, jako delegaci kapituły wileńskiej (biskupstwo wówczas wakowało po przejściu w r. 1591 kard. Jerzego Radziwiłła do Krakowa), kanonicy Benedykt Woyna i Grzegorz Święcicki ${ }^{232}$, którzy później tak gorliwie zajmowali się sprawą kanonizacji. Tuż po zakończeniu sejmu kapituła została powiadomiona (21 IV 1600 r.) o nominacji Woyny przez króla na biskupstwo wileńskie ${ }^{233}$. Nie wracał on już po tym do Wilna, ale wprost z Warszawy udał się do Rzymu, by wyprosić zatwierdzenie papieskie ${ }^{234}$. Uzyskał je 31 lipca 1600 r. ${ }^{235}$ Resztę czasu w wiecznym mieście poświęcił na załatwianie uzgodnionej wcześniej z królem (jak informują potem Swięcicki i Skarga) ${ }^{236}$ kanonizacji bł. Kazimierza, skoro po powrocie przedstawił kapitule 13 VII 1601 r. dosyć dziwną bullę Klemensa VIII z odpustami na jak pisze autor streszczeniz niedostępnych dziś akt kapituły ks. Kurczewski - uroczystości św. Stanisława i św. Kazimierza ${ }^{237}$.

Dalszy ciąg starań o kanonizację po powrocie Woyny z Rzymu jest już przynajmniej częściowo udokumentowany. Dnia 1 lutego $1602 \mathrm{r}$. kapituła, „na instancję" biskupa, wydelegowała do wiecznego miasta kanonika Grzegorza Święcickiego „dla otrzymania kanonizacji bł. Kazimierza" ${ }^{288}$; 15 marca tegoż roku dano mu na podróż ze skarbca Królewicza 300 czerwonych złotych ${ }^{239}$, a później — już w czasie załatwiania sprawy w Rzymie - 17 I 1603 r. dalsze 400 zł „,na dokończenie interesu kanonizacji bł. Kazimierza" ${ }^{240}$. Wyjeżdżający poseł wiózł prawdopodobnie osobiście także petycje $\mathrm{w}$ tej sprawie, skierowane do kardynała sekretarza stanu Piotra Aldobrandiniego: od króla Zygmunta III (z 16 III 1602 r.) oraz od biskupa Woyny ${ }^{241}$.

231 Zob. Hp 1 s. 447.

${ }^{232}$ Mandat otrzymali 21 I 1600 r. (zob. J. Kruszewski, Kościót zamkowy, t. 3 s. 85$)$.

${ }^{233}$ Tamże, s. 85.

234 Tamże, s. 86.

${ }^{285}$ Zab. Relationes status dioecesium in Magno Ducatu Lituaniae. Ed. P. Rabikauskas SJ, t. 1, Romae 1971, s. 20.

s. 1161.

${ }^{236}$ Zob. Oratio Svencicii, [w:] Theatrum, s. 65; P. Skarga, Żywoty świętych,

${ }^{287}$ J. Kruczewski, jw., s. 87.

238 Tamże, s. 87.

289 Tamże, s. 88.

240 Tamże, s. 88.

241 Zob. F. Niewiero, jw., s. 87. Obydwa listy znajdują się w Archiwum Watykańskim, Fondo Borghese, III 96 A-B k. 25-32 i 128. 
W wyniku działań rzymskich Swięcickiego Klemens VIII podpisał w dniu 7 XI 1602 r. bullę zaczynającą się od słów „Quae ad Sanctorum”, mocą której, na prośbę króla Zygmunta III i „po wysłuchaniu kardynałów członków Kongregacji św. Obrzędów i Ceremonii, pozwala w całym Królestwie Polskim i Wielkim Księstwie Litewskim oraz we wszystkich krajach im podległych [...] obchodzić uroczyście dzień św. Kazimierza Wyznawcy", z oficjum mszalnym i brewiarzowym rytu zdwojonego ${ }^{242}$. Nie jest to więc dekret kanonizacyjny w ścisłym tego słowa znaczeniu. Papież o motywacji swego pozwolenia na sprawowanie mszy św. o Swiętym, powołuje się na fakt, że był on ,a felicis recordationis Leone Papa Decimo, Praedecessore Nostro, in sanctorum numerum adscriptus" ${ }^{243}$.

Skąd ta pewność? Czy przeprowadzano w tej sprawie jakiekolwiek badania? Oczywiście. Zaostrzenie kryteriów wynoszenia na ołtarze w Kościele potrydenckim nie pozwala suponować, że papież i kolegium kardynalskie podjęło decyzję pochopnie i bez dochodzenia prawdy. O tym, że szukano dawnej dokumentacji w kurii rzymskiej i zlecono biskupowi Woynie jeszcze w czasie jego pobytu w Rzymie w r. 1600/1 przeprowadzenie weryfikacji wcześniejszych procesów - świadczy otwarcie grobu Kazimierza w katedrze wileńskiej w r. 1602, jeszcze przed wyjazdem Święcickiego do Rzymu ${ }^{244}$. Biskup musiał wiedzieć, że w żadnym wypadku nie wolno mu było tego dokonać, gdyby nie otrzymał jakiegoś $\mathrm{w}$ tej sprawie zlecenia.

Jeśli jest prawdą, że jeszcze 6 IX 1601 r., zaraz po powrocie Woyny z Rzymu, Zygmunt III prosił papieża (z Wilna) nie o kanonizację Kazimierza, lecz tylko o to, co później otrzymano, mianowicie wprowadzenie do mszału i brewiarza specjalnego oficjum o nim ${ }^{245}$, to można $z$ dużą dozą prawdopodobieństwa, choć nie bez ryzyka przyjąć, że także w wiecznym mieście w czasie pobytu tam Woyny szukano akt procesu Ferreriego i nie znalazłszy ich poprzestano na zreferowanej przez biskupa opinii, wyrażonej przez Swięcickiego, że kanonizacja ta rzeczywiście miała miejsce, a tylko jej dokumentacja zaginęła i wobec tego - nie chcąc ryzykować powtórnego dokonywania tego, co już raz mogło być dokonane Klemens VIII zdecydował się na nieformalne zatwierdzenie kultu, wciąż przecież żywego. Takim właśnie nieformalnym zatwierdzeniem jest znane w praktyce Kościoła do dziś (,,beatyfikacja” bł. Królowej Jadwigi przez odprawienie mszy św. o niej w Krakowie w czerwcu 1979 r. przez pa-

242 Tekst bulli oraz załączonego do miej oficium wydał Swięcicki w swoim Theatrum (s. 25-27), skąd przedrukowal go J. Kruczewski jw., 2 s. 284 286).

248 Theatrum, s. 26.

244 Zob. $\mathrm{N}$ i e w i er o, jw., s. $87-88$.

245 Zaginiony dziś list znajdowal się w archiwum rodziny Doria w Rzymie. Jego streszczenie podal L. Pastor: Geschichte der Päpste, Bd 11, Freiburg im Br. 1922 , s. 482. 
pieża Jana Pawła II) pozwolenie na odprawianie mszy św. i brewiarza o osobie nie kanonizowanej (lub od XVII w. nie beatyfikowanej), ale powszechnie czczonej. Akt taki, szeroko omówiony i uzasadniony przez papieża Benedykta XIV w jego dziele De Servorum Dei beatificatione et beatorum canonisatione (Rzym 1747), nazywa się beatyfikacją lub kanonizacją równoznaczną (aequipollens).

W każdym razie odwołanie się Klemensa VIII do kanonizacji Kazimierza za Leona $\mathrm{X}$ nie jest i nie może być traktowane jako zatwierdzenie tejże kanonizacji, jak chcą niektórzy współcześni historycy ${ }^{246}$, gdyż nigdy żaden papież takich aktów swoich poprzedników nie potwierdzał. Nie może też być traktowane jako autorytatywne stwierdzenie faktu tamtej kanonizacji, gdyż nie o niej, ale o pozwoleniu na czczenie Kazimierza jako świętego orzeka. Stąd jest zrozumiałe, dlaczego nie było w Rzymie w r. 1602 uroczystości kanonizacyjnej, a sztandar z postacią Świętego, jaki się zwykło na takie uroczystości wywieszać, został ofiarowany przez życzliwego Polsce papieża Klemensa VIII tylko jako symbol na zaprogramowane wcześniej uroczystości wileńskie.

Odbyły się one w Wilnie 10 maja 1604 r., wyreżyserowane przez jezuitów z taką pompą, jakiej miasto od początku swego istnienia nie widziało. Barwne pochody, bajecznie poubierane alegoryczne figury, recytacje poetyckie uczniów szkół jezuickich - wszystko to miało świadczyć o ostatecznym triumfie Kazimierza i wiary katolickiej oraz ich definitywnym zwycięstwie nad herezjami, potwierdzonym nawet przez niezwykłe znaki w naturze (bocian nad miastem), jakie tym uroczystościom towarzyszyły ${ }^{247}$.

Od tej pory propagowanie kultu św. Kazimierza przejmą w swe ręce jezuici. Swięty Królewicz, młody, mądry, czysty był idealnym wzorem dla wychowanków ich kolegiów i dlatego wnet stanął, jak brat syjamski, w szeregu jezuickich młodzianków z lilią w ręku obok Alojzego Gonzagi, Jana Berchmansa i Stanisława Kostki. Odtąd też jest coraz bardziej czczony jako patron litewskiej części Rzeczypospolitej Obojga Narodów.

246 Zob. Ni e wi e ro, jw., s. 84. Nawet samą bulle Klemensa VIII nazywa on „kanonizacyjną" (!). P. Skarga, świadom tych trudności, nazwał akt Klemensa VIII ,wsłowieniem" kanonizacji leoniańskiej (Żywoty świętych, Kraków 1610 , s. 1162).

247 Zob. Theatrum, passim. Syntetycznie opisują te uroczystości, na podstawie licznych drukowanych relacji współczesnych: J. Biciunas, Commémoration de la fàte célébrée, a Wilno en 1604 à l'occasion de la canonisation de St. Casimir, „Antemurale" 1 (1954) s. 126-131; P. R a bika u sk a s, Didžiosios šv. Kazimiero Sventes Vilniuje 1604 ir 1636 [Największe uroczystości ku czci św. Kazimierza w Wilnie 1604 i 1636], „Aidai” 1958, s. 118-128. 


\title{
BEGINNINGS OF THE CULT AND THE CANONISATION PROCESSES
}

OF ST. CASIMIR

\author{
Sum mary
}

On the basis of the hitherto existing literatur and new sources, the author attempts to pinpoint the beginnings of the cult of St. Casimir Jagiellon, the Polish Royal Prince (1458-1484), and to solve the tangled problem of his canonization. Having discussed the canonization processes of that time, the author shows that in the first years after his death the cult of St. Casimir concentrated on his virtues of justice and wisdom, which indicated the ideal of the Christian ruler. At the same time, there appear the first signs of the religions honour paid to him, as evidenced by his tomb in the Cathedral in Wilno. In 1501 Pope Alexander VI granted an indulgence to those visiting the chapel in which Casimir's body was buried. This was an automatic permission, as the author assumes, to honour Casimir publically, which suggests also permission to use the title „Blessed”. This hypothesis - confirmed by evidence of the cult (votive offerings by his tomb) and the information about the miracles occurring in Wilno - disproves the existing conviction of historians that the cult of St. Casimir originated only after the Battle of Polock in 1518, in which the Polish army defeated the Muscovites. This hypothesis first appeared in historiography due to the assiociation of this victory attributed to the Royal Prince, with the one described in 1520 by the first biographer of the Saint, Nuncio Zaccaria Ferreri, also as a miracle worked by Casimir. The Nuncio asserts that it was after this victory that the efforts to canonize him commenced. The author analyzes Ferreri's description of the victory, and - by comparing it with the contemporary descriptions of other battles - he discover that in his account the Nuncio relates it to the victory of the Polish army over Moscow at Orsza on 8th September, 1514. It was after this victory, in October 1514, that King Sigismundus I commenced efforts in Rome to canonize his saintly brother. The abundant authorized documentation does not leave any doubts as to the King's frequent requests with Pope Leo X to begin the process in 1514, 1515 and in 1517, as a result of which (thanks to the favounable political situation and the diplomatic skills of the King's Legate, Wawrzyniec Międzyleski) the process was initiated. At the Papal Consistory on 4th November 1517, Jan Easki, Archbishop of Gniezno, was appointed Commissioner to perform the process of canonization. He carried out the first process in Wilno in August 1518, and sent the records ta Rome. After examining them, the Pope appointed another commisioner, Nuncio Zaccaria Ferreri, who carried out the second process in Wilno at the close of 1520 . The records, as well as the biography of the Royal Prince, written on the basis of the accounts of eye witnesses, were brought to Rome by Ferreri in the autum of 1521 .

It is not known what followed. The problem of canonizing St. Casimir was not returned to till the end of the 16th century. It was King Sigismundus III Vasa, who - wishing to strengthen his dynasty by the canonisation of his near relative, Casimir (the Vasa dynasty was related to the Jagellons through Sigismundus III's mother, Katarzyna, daughter of Sigismundus I) applied to the Apostolic See for the canonization. As a result of these efforts undertaken by the Bishop of Wilno, Benedykt Woyna, and Canon Grzegorz Swiecicki, on 7th November 1602 Pope Clement VIII issued the Bull Quae ad Sanctorum, which confirmed (by virtue of 
the 1521 "canonization") the permission to celebrate the Mass (both Latin and Uniat) of the Saint all over Poland and Lithuania. In his work Theatrum Sancti Casimiri (Wilno 1604), Canon Swięcicki writing aboul the efforts, quotes a till unidentified source, saying that Pope Leo $\mathrm{X}$ ordered the investigation of the records of the process performed and brought to Rome by Ferreri in 1521, that he confirmed them and solemnly canonized Casimir in the same year, passing the canonization bull to the Polish Legate in Rome, Erazm Ciołek, Bishop of Plock. The latter, however, died in Rome in 1522 and all his belongings, including this Bull, were destroyed. The story was long believed in, until Jan Fijałek in 1924 and finally Florian Niewiero in 1970 proved that no such circumstance could have ever taken place. As a consequence of this ascertainment, the Bull of 1602 by Pope Clement VIII is not and cannot be the confirmation of the canonization in 1521 , as all the present-day historiobiographers (excluding Paul Rabikauskas) would have it but only the tantamount carlonization (equipollens), i.e., recognition of the cult allowing the Mass and the Breviary of the Saint to be said. 